\title{
Laophontopsis Sars and the taxonomic concept of the Normanellinae (Copepoda: Harpacticoida): A revision*
}

\author{
Rony Huys \& Kris A. Willems \\ Marine Biology Section, Zoology Institute, State University of Gent, K.L. Ledeganckstraat 35, B-9000 Gent, \\ Belgium; Delta Institute for Hydrobiological Research, Vierstraat 28, 4401 EA Yerseke, The Netherlands
}

Keywords: Copepoda, Harpacticoida, Laophontopsidae, Normanellinae, Cletopsyllinae n. subfam., Telodocus n. gen., Aculeopsis n. gen.

\begin{abstract}
The taxonomic concept of the subfamily Normanellinae Lang (Harpacticoida, Laophontidae) is revised. As a result a new family Laophontopsidae is proposed to accommodate Laophontopsis Sars and two new genera Aculeopsis and Telodocus. It is concluded that the presumed boreo-mediterranean distribution pattern displayed by the type species $L$. lamellifera (Claus) is merely the result of erroneous identifications. The population of northwest Europe is assigned to a new species $L$. borealis and another new species $L$. monardi is proposed for Monard's (1928) material from Banyuls-sur-Mer. $L$. secundus Sewell is placed in the new genus Telodocus. Aculeopsis gen. nov. embraces only $A$. longisetosa spec. nov. and constitutes the most primitive genus of the family. The Laophontopsidae are placed within the superfamily Laophontoidea. The Normanellinae are provisionally upgraded to family level despite their diphyletic status because this narrows the diagnosis of the Laophontidae considerably. The genera are attributed to two clearly defined but non-related subfamilies, Normanellinae Lang (Normanella Brady) and Cletopsyllinae subfam. nov. (Cletopsyllus Willey, Pseudocletopsyllus Vervoort). The genus Pseudocleta Lang is relegated to incertae sedis within the Laophontoidae.
\end{abstract}

\section{Résumé}

Révision du cadre taxonomique de la sous-famille des Normanellinae Lang (Harpacticoida, Laophontidae); et proposition d'une nouvelle famille, les Laophontopsidae, incluant Laophontopsis Sars et deux nouveaux genres Aculeopsis et Telodocus. La distribution boréo-méditerranéenne présumée de l'espèce-type $L$. lamellifera (Claus) est due uniquement à des identifications erronées; la population du Nord-ouest de l'Eu- rope est attribuée à $L$. borealis $\mathrm{sp}$. n. et $L$. monardi $\mathrm{sp}$. n. est proposée pour le matériel de Monard (1928) provenant de Banyuls-sur-Mer. $L$. secundus Sewell est transférée dans le nouveau genre Telodocus. Le genre Aculeopsis gen. nov. est considéré comme le plus primitif de la famille et ne comprend que l'espèce nouvelle $A$. longisetosa. La famille des Laophontopsidae est attribuée à la superfamille des Laophontoidea. Bien qu'ayant un statut diphylétique la sous-famille des Normanellinae est provisoirement élevée au niveau de famille, comprenant deux sous-familles bien définies mais non apparentées: les Normanellinae Lang (Normanella Brady) et les Cletopsyllinae subfam. nov. (Cletopsyllus Willey, Pseudocletopsyllus Vervoort). De cette manière la diagnose de la famille des Laophontidae est considerablement allégée. Le genre Pseudocleta Lang est considéré comme incertae sedis dans la superfamille des Laophontoidea.

\section{Introduction}

The long and complicated history of Laophontopsis lamellifera (Claus, 1863) started with the establishment of Claus' (1863) composite taxon Cleta uniting Harpacticus fortificationis Fischer and the new species $C$. serrata, $C$. brevirostris and $C$. lamellifera. Brady (1872) listed the latter under the name Laophonte lamellifera. After being synonymized in its broadest sense with Laophonte Philippi, 1840, Cleta subsequently became part of the new subfamily Canthocamptinae (Brady, 1880). This state of affairs was also adopted by Canu (1892) but not by T. Scott (1905), who created the Laophontidae, un-

\footnotetext{
* Contribution No 446 of the Delta Institute for Hydrobiological Research, Yerseke.
} 
fortunately without diagnosing the family, to accommodate Laophonte. A revision of the latter prompted Sars (1908) to transfer Laophonte lamellifera to the new genus Laophontopsis, but he nevertheless retained the species in the Laophontidae. Sewell (1924) in his great work on the Chilka Lake, pointed out that $C$. lamellifera should by the rules of priority of nomenclature be regarded as the type of Claus' genus, implying the relegation of Laophontopsis to a synonym of Cleta. Sewell's nomenclatural act did not gain wide acceptance as is exemplified by for instance Monard, who continued to use Laophontopsis in many of his works $(1928,1935 a ; 1935 b, 1937)$ and in his "Synopsis universalis generum Harpacticoidarum" (1927). At last, the reinstatement of Cleta seemed to have settled with the publication of Lang's (1948) monograph. Unfortunately, neither Sewell (1924) nor Lang (1948) were aware of the fact that the name Cleta had been applied already for both a lepidopteran (Duponchel, 1844: 271) and a coleopteran (Mulsant, 1850: 866, 1096). Claparède (1870: 539) used it also as a replacement name for Vanadis (Polychaeta). Nicholls (1941: 92) and Lang himself (1965: 447) rectified this misunderstanding.

Lang (1948) divided the Laophontidae into three subfamilies: Laophontinae, Normanellinae and Donsiellinae. The latter were removed to the Thalestridae and recognized as being the closest relatives of the Pseudotachidiinae (Hicks, 1988; Huys, 1988a). The Normanellinae were established by Lang (1948) to accommodate the genera Cleta, Normanella Brady, Cletopsyllus Willey and Pseudocleta Lang. In his revision of the Laophontidae Nicholls (1941) provisionally allocated Normanella and Cletopsyllus to the Canthocamptidae because this would narrow significantly the diagnosis of the Laophontidae. Inspired by Willey (1935), Nicholls (1945) later formally established the family Normanellidae to include these two genera. Lang (1948) briefly discussed Nicholls' papers in a postscript and pointed out that the subfamily Normanellinae had already been introduced by him in a provisional communication (Lang, 1944: 38) on his monograph, and for that reason deserved priority over Nicholls' family name. This being true, and for the sake of consistency, almost all of the taxa coined in
Lang's monograph should in fact be quoted as being established in 1944. Nevertheless, the family Normanellidae Nicholls has frequently been used in recent literature when new species were discovered (Soyer, 1966; Itô, 1971, 1972).

Lang (1948) recognized two groups within the Normanellinae on the basis of the armature on leg 1 and endopod P2: Cleta - Pseudocleta and Cletopsyllus - Normanella. However, in our opinion the subfamily in Lang's sense is nothing more than a repository for "laophontid-like" genera which are too primitive to justify their incorporation into the Laophontinae sensu Lang. In the light of a phylogenetic analysis of the relationships within the superfamily Laophontoidea (Huys, in press a), we purposely define the Laophontidae as being equivalent to Lang's Laophontinae, taking into account the aberrant Namakosiramia Ho \& Perkins (Huys, 1988a) but excluding the specialized genus Pholenota (Huys, in press b) and Sarsocletodes (Huys, in press c). Except for Laophontopsis, none of the normanellid genera bear any direct relationship to the Laophontidae. Moreover, comparison of their respective diagnoses raises grave doubts as to the validity of the current taxonomic concept of the Normanellinae. We therefore suggest to provisionally assign these genera to two subfamilies within the Normanellidae Lang, viz. Normanellinae (Normanella) and Cletopsyllinae subfam. nov. (Cletopsyllus - Pseudocletopsyllus). Pseudocleta is ranked as incertae sedis whilst re-examination of the genus Laophontopsis justified the establishment of a novel family within the Laophontidae.

\section{Materials and methods}

Specimens were dissected in lactic acid and the dissected parts were placed in lactophenol mounting medium. Preparations were sealed with glyceel (Gurr ${ }^{\star}$, BDH Chemicals Ltd, Poole, England).

All drawings have been prepared using a camera lucida on a Leitz Dialux 20 interference microscope. The terminology is adopted from Lang $(1948,1965)$ except for (1) the terms pars incisiva, pars molaris and lacinia mobilis, which are omitted in the description of the mandibular gnathobase (Mielke, 1984), (2) the segmental composition of the mandible and maxilliped which are followed according to Boxshall (1985: 341-345). The setae of the caudal rami are named and numbered as proposed by 
Huys (1988b). Abbreviations used in the text and figures are: A1, antennula; A2, antenna; P1-P6, first to sixth thoracopods; exp., exopod; enp., endopod; exp(enp)-1(-2, -3$)$, to denote the proximal (middle, distal) segment of a ramus.

\section{Systematics and discussion}

\section{Establishment of the Laophontopsidae fam. nov.}

Family LAOPHONTOPSIDAE fam. nov.

\author{
Canthocamptinae Brady, 1880 (part.) \\ Laophontidae T. Scott, 1905 (part.) \\ Normanellinae Lang, 1944 (part.)
}

Diagnosis. - Body cylindrical, no clear demarcation between prosome and urosome. First pedigerous somite fused to cephalosome. Epimeral plates of thoracic somites slightly developed. Cephalic shield almost rectangular in dorsal aspect. Rostrum large and broad, completely defined at the base; with two sensillae and a ventral, subterminal tubepore. Female genital double-somite with internal, transverse, chitinous rib both laterally and dorsally. Anal operculum weakly developed; pseudoperculum absent. Caudal rami cylindrical or tapering distally, slightly depressed, with 7 setae (all reduced). Sexual dimorphism in antennula, probably endopod P2 (outer apical seta enp-2 shorter), endopod P3 (outer seta of enp-2 modified into an apophysis; 2-segmented), P5, P6, caudal rami and in genital segmentation.

Antennula short, with or without outer spinous process on segment II; with numerous pinnate setae and spines; 4-segmented in female, with aesthetasc on segments III and IV; 5-segmented and modified (segment IV extremely swollen, segments distal to geniculation fused) in male with geniculation between segments IV and V and with aesthetascs on segments IV and V. Antenna with allobasis bearing one abexopodal seta and tetrasetose (or trisetose), unisegmented exopod; endopod with 6 distal elements and 2 spines laterally. Labrum undivided, with few apical ornamentation. Mandible with unisegmented palp; endopod represented by distal process with 3 setae and 1 spine, exopod with 1 seta standing on small process. Paragnaths well developed, strongly ornamented lobes. Maxillule with unisegmented, bisetose exopod; endopod incorporated into basis, with 3 setae; basal endites well defined, proximal one with 2 setae, distal one with 1 claw and 2 setae. Maxillary syncoxa with 3 endites, precoxal endite vestigial (with 1 seta); endopod unisegmented, with 3 setae. Maxilliped with syncoxa bearing 1 seta; basis asetose; endopod unisegmented with 1 minute seta and 1 long claw.

P1 with well developed 3-segmented protopod; basis with inner spine located at the inner margin and not on the anterior surface; exopod 3-segmented, distal segment with 2 spines and 2 geniculate setae; endopod prehensile, 2-segmented with elongated enp- 1 bearing inner seta and short enp- 2 with 1 long claw (plus 1 short claw or 1 long, geniculate seta). P2-P4 with 3-segmented exopods and 2-segmented endopods; spine- and seta formulae as follows:

$\begin{array}{lll} & \text { Exopod } & \text { Endopod } \\ \text { P2 } & 0.1 .12[2-3] & 0.120 \\ \text { P3 } & 0.1 .22[2-3] & 0.121 \\ \text { P4 } & 0.1 .[1-2] 2[2-3] & 0 .[0-1] 21\end{array}$

Female fifth pair of legs not fused medially, defined at the base, intercoxal sclerite absent, exopod and baseoendopod separate; exopod with 5-6 setae; endopodal lobe well developed, with 5 setae; basal seta standing on short setophore. Position and segmentation of male fifth pair of legs similar to female; endopodal lobe with 2 setae; exopod with 5 setae; basal seta arising from short setophore.

Female gonopores fused medially and each covered laterally by vestigial P6 bearing 2 setae; copulatory pore large, located in median depression, partly concealed beneath integumental fold; seminal receptacles paired, well defined. One egg-sac.

Male P6 asymmetrical, with 2 setae each; either left or right P6 fused to ventral wall of supporting somite, other member articulating and closing off gonopore. Reproductive system asymmetrical with single functional gonopore releasing one spermatophore at a time. Male grasping terminal setae of 
female's caudal rami during precopulatory phase. Marine, freeliving.

Type genus. - Laophontopsis G.O. Sars, 1908 Other genera. - Aculeopsis gen. nov.; Telodocus gen. nov.

Genus Laophontopsis G.O. Sars, 1908

Cleta n.g. Claus, 1863 (part.)

Laophonte Philippi, 1840 (part.)

Diagnosis. - Laophontopsidae. Antennule without spinous outer process on segment II; in female without trace of incomplete division on segment IV. Antennal exopod with 4 setae. P1 with exp-2 longer than other exopod segments; enp-1 with short inner seta, enp-2 with 1 long and 1 short unipinnate claw. Exp-3 P2-P4 with 2 outer spines. Exp. P5 longer than endopodal lobe; with 6 setae and/or spines. Caudal rami about twice as long as anal somite; inner terminal seta (V) longest, setae IV and VI reduced.

Type species. - Cleta lamellifera Claus, 1863 [by monotypy]

Other species. - Laophontopsis borealis spec. nov.; $L$. monardi spec. nov.

Laophontopsis lamellifera (Claus, 1863)

Cleta lamellifera Claus, 1863: 123-124, Taf. XV Abb. 21-24.

Remarks. - The original description of Cleta lamellifera by Claus (1863), based on material from Messina, Italy, shows many inaccuracies and cannot be used as a reliable reference for identification purposes. Despite the very incomplete and poor drawings of Claus' type species, all subsequent boreo-mediterranean finds of Laophontopsis were assigned to L. lamellifera. An almost identical, but even more intricate, case is found in the literature on Orthopsyllus linearis Claus, where the inadequate description of the mediterranean type species and the subsequent misquoting of boreal populations under the same name has led nowadays to a virtually unsolvable taxonomic mess. Comparison of Brady's (1880) and Sars' (1908) illustrations of L. lamellifera shows not only that they were dealing with the same species, but also that there are at least two significant points of difference with Claus' material. The specimens from Messina are characterized by a long and slender endopod P1 which is 3.0 times as long as the exopod; this puts the implantation of the inner seta of enp-1 in a position definitely distal to the apical margin of exp-3. The material from northwestern Europe shows a more robust endopod $\mathrm{P} 1$ which is only $2.3-2.4$ times the exopodal length; here the distal margin of exp-3 reaches about the implantation site of the inner seta of enp-1. Secondly, Claus' animals have relatively longer and more slender caudal rami compared to the boreal specimens. Although we recognized a certain degree of variability (see below) in the shape of the caudal rami of the latter, it is definite that the condition displayed by the mediterranean population falls without that range. Moreover, the outer terminal seta (IV) is much longer. After re-examination of material collected in Britain and in The Netherlands, we conclude that the population of northwest Europe represents a different species. Other mediterranean records of $L$. lamellifera were given by Monard $(1928,1935 \mathrm{~b}, 1937)$ and Bodin (1964). Those from Salammbô (Monard, 1935b) and Alger (Monard, 1937) are not accompanied by any illustrations or morphological indications and hence, they cannot be assigned with certainty to Claus' species. Monard's (1928) drawings give sufficient evidence that he was dealing with a different species (see below). Re-examination of Bodin's (1964) single specimen from Marseille revealed that it represents a separate genus. Thus, the presence of several Laophontopsidae in the Mediterranean further reinforces that a boreo-mediterranean distribution for $\boldsymbol{L}$. lamellifera is an unlikely supposition.

\section{Laophontopsis borealis spec. nov.}

Laophonte lamellifera Brady, 1872: 437; 1880: 83-85, pl. LXXV figs. 15-23; 1902: 56; 1904: 4; Calderwood, 1886: 151; Canu, 1892: 163; Herdman, 1891: 43; Norman, 1886: 24; Norman \& T. Scott, 1906: 160; Pearson, 1905: 150; A. Scott, 1896: 127; T. Scott, 1888: 240; 1897: 151; 1903: 119; 1906: 333; Thompson, 1889: 187; 1890: 638; 1893: 200, pl. 20 fig. 8. Laophonte lamelligera Giard, 1888: 504, lapsus calami. 
Laophontopsis lamellifera Sars, 1908: 266-267, pl. CLXXXV; Bodin \& Boucher, 1981: 340; Bodin, 1976: 36; 1977: 85; 1988: 109; Bruce et al., 1963: 124; Farran, 1913: 15; Geddes, 1972: 74; Hicks, 1980: 164; Hockin, 1982: 731; Hockin \& Ollason, 1981: Table IV; Jakubisiak, 1936: 320; Monard, 1935a: 73, figs. 206-207; Moore, 1973: 130, 148; Norman \& Brady, 1909: 389; O'Riordan, 1971: 205; Wells, 1970: 267.

Cleta lamellifera Barnett, 1968: 189-190; Bossanyi \& Bull, 1971: 45; O'Riordan, 1966: 72; Wells, 1964: 454; Williams, 1954: 365 .

Description. - Based on material from the Eastern Scheldt (The Netherlands) with additional notes on variability from other specimens obtained by $\mathrm{Dr} R$. Hamond.

Female (figs. 1A-B; 2A-D; 3A-D; 4A-E; 5A, $\mathrm{C}, \mathrm{E}, \mathrm{F} ; 6 \mathrm{C})$. - Total body length $820 \mu \mathrm{m}$ from the tip of the rostrum to the posterior margin of the caudal rami. Maximum width $175 \mu \mathrm{m}$ measured at the posterior margin of the cephalothorax. Rostrum (figs. 1A, B; 4B) with broad base, slightly deflexed, bell-shaped, tapering to trilobed apex, ornamented with a pair of tiny setules subterminally and a midventral tube-pore near the apex. Body (figs. 1A, B) cylindrical, with deep constrictions between the somites, covered with minute denticles both laterally and dorsally (fig. 4A); integument with numerous large, irregular, cuticular depressions arranged either in narrow bands circumscribing anterior half of thoracic and abdominal somites, or in more or less symmetrical patches distributed over the cephalic shield. Cephalothorax almost rectangular in dorsal view, grossly produced ventrally; posterior margin with few minute protuberances. Pleurotergites of thoracic somites with denticulate hind margin; P5-bearing somite without ventral ornamentation (fig. 4A). Last thoracic somite and first abdominal somite completely fused and forming a large genital double-somite (figs. 1A, B; 4A) slightly tapering anteriorly; original segmentation marked by dorsal and lateral internal chitinous ribs and external ornamentation consisting of sensillae and obtuse protuberances; thoracic (anterior) half with pitted sculpturing. Free abdominal somites with small spinules interspersed with minute protuberances along the hind margin (fig. 4A). Anal somite (figs. $1 \mathrm{~A}, \mathrm{~B} ; 2 \mathrm{C} ; 4 \mathrm{~A}$ ) with denticulate, weakly developed operculum flanked by two tiny sensil- lae; anal vestibulum pentagonal, lateral margins pectinate, hind margins formed by spinular row on caudal rami (fig. 2C). Caudal rami (figs. 2C, D; 4A) lamelliform, long, about 3.1 times as long as maximum width; slightly tapering posteriorly; with 7 setae: VII tri-articulated at base, plumose and located near anterior margin; terminal setae reduced, IV and $\mathrm{V}$ with diminutive denticles in distal half, $\mathrm{VI}$ pinnate.

Antennula (fig. 2A) 4-segmented, very short. Segment I with several spinular rows; segment II without spinous, outer process; segment III longest. Setal ornamentation: I-1; II-[2 +7 pinnate]; III-[6 + 5 pinnate + aesthetasc]; IV-[11 pinnate + aesthetasc].

Antenna (fig. 3B) with spinular row on coxa; allobasis with minute spinules proximally and a plumose abexopodal seta; exopod small, with 2 plumose setae laterally and 2 pinnate setae apically; endopod with 2 curved spines laterally, with 2 curved spines and 3 geniculate setae distally (outermost geniculate seta bipinnate and fused with short seta).

Labrum (fig. 5F) a simple muscular lobe with 2 pores and coarse spinules laterally and with fine spinules medially.

Mandible (fig. 4C) with well developed gnathobase bearing several multicuspidate teeth and a pinnate recurved spine; palp biramous: basis with 1 plumose seta, endopod represented by apical process with 3 plumose setae and 1 bipinnate spine, exopod a small process with 1 seta.

Paragnaths (fig. 5E) well developed and heavily ornamented with fine spinules; with bilobed process in between.

Maxillula (fig. 4D) with well developed arthrite armed with 8 terminal spines, 2 inner setae and 2 setae on posterior surface; coxa with spinular row and 1 curved spine plus 1 seta on its endite; basis with two endites (proximal with 2 setae; distal with 2 setae and 1 claw); endopod represented by 3 setae; exopod unisegmented, with 2 setae.

Maxilla (fig. 4E) with 3 endites on syncoxa; proximal (precoxal) endite obsolete, with 1 seta, coxal endites with 3 pinnate spines each; basis produced into a claw-like endite with 2 setae and 1 claw; endopod 1-segmented with 3 setae. 


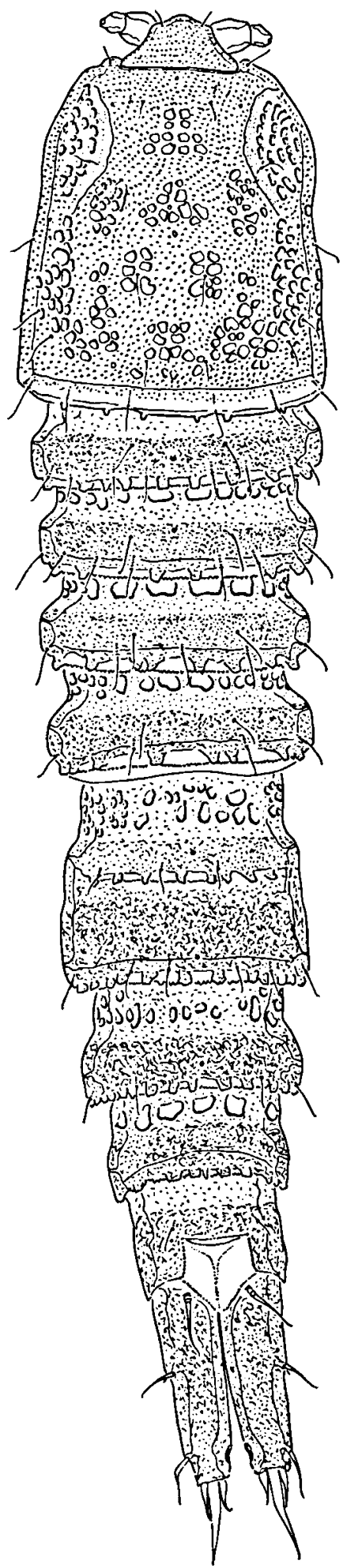

A
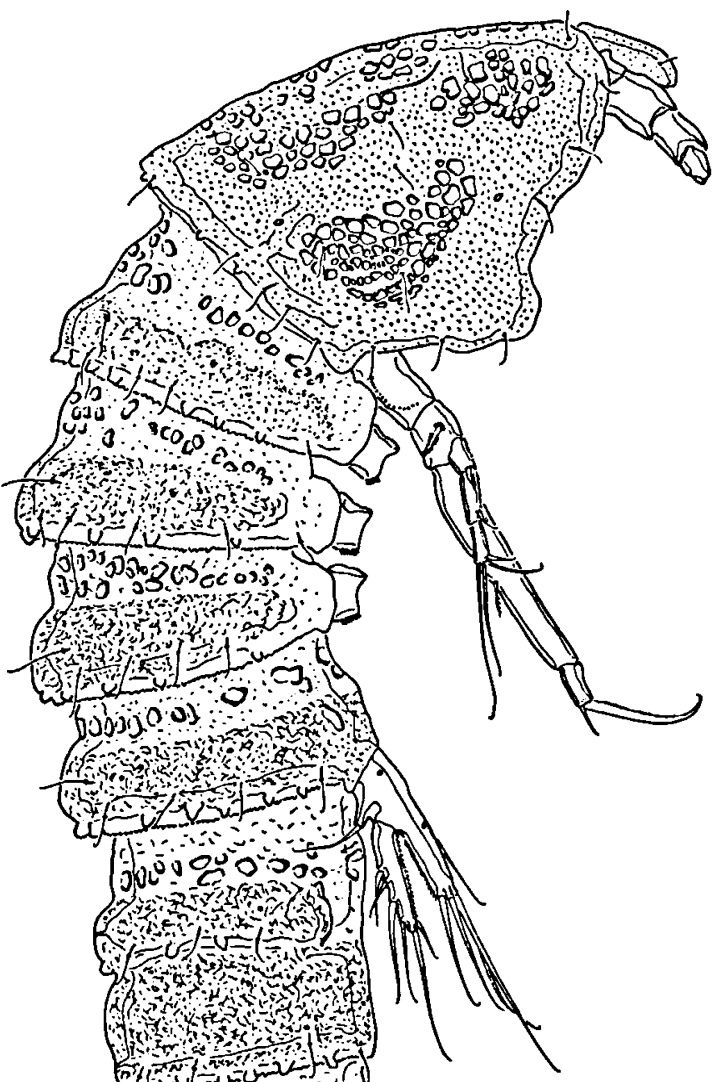

(n)

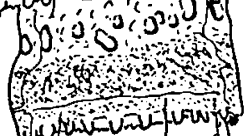

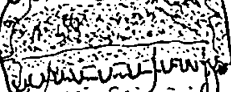

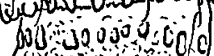

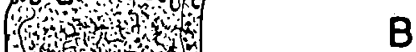

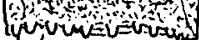

B
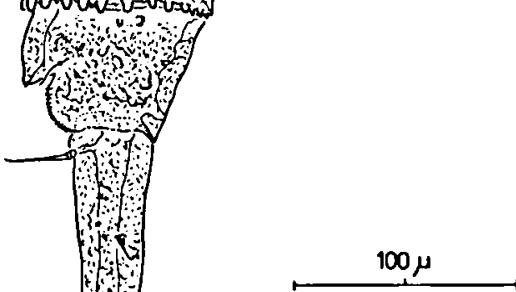

Fig. I. Laophontopsis borealis n. sp.: A, habitus, female (dorsal view); B, habitus, female (lateral view). 


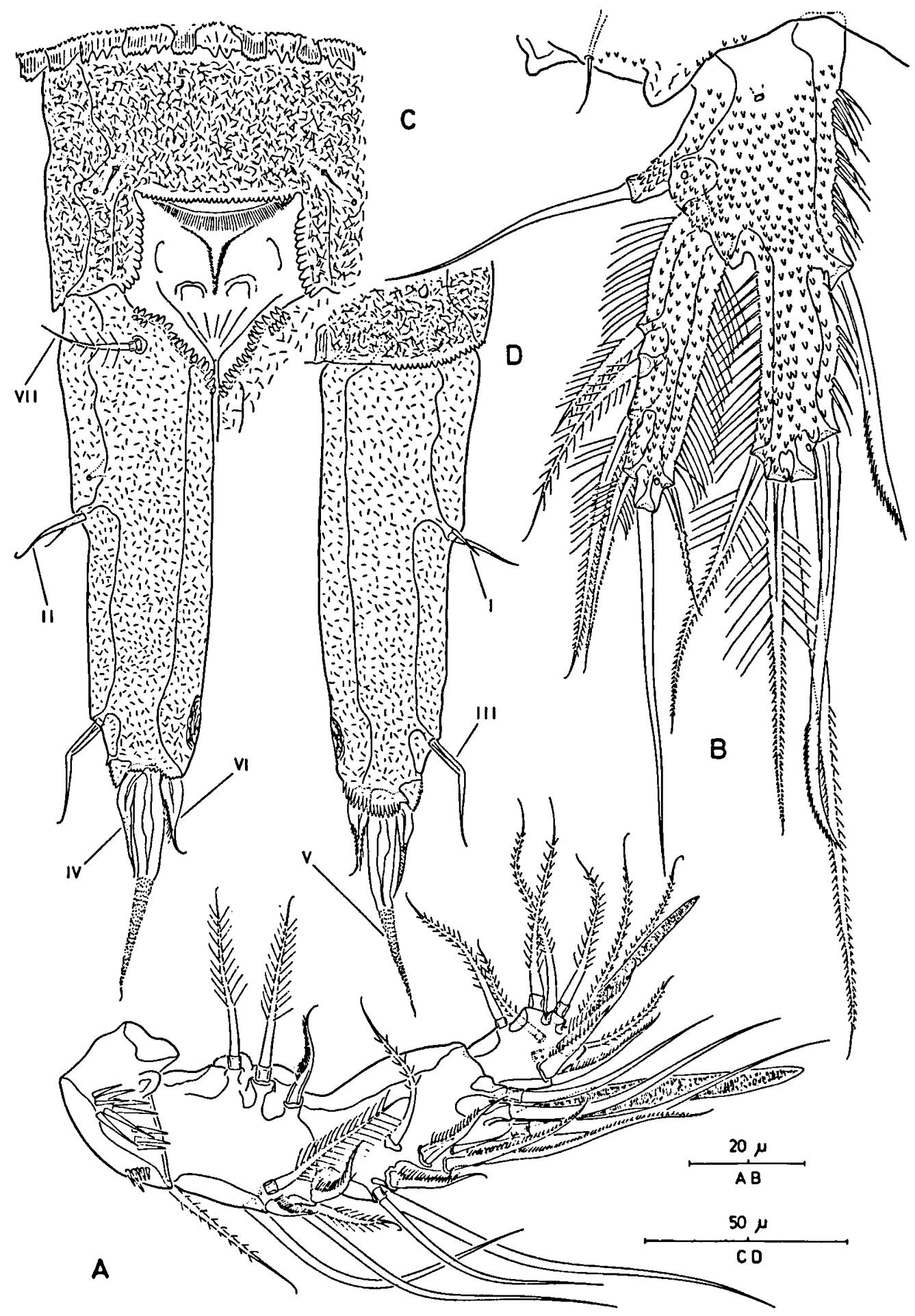

Fig. 2. Laophontopsis borealis $\mathrm{n}$. sp.: A, antennula, female; B, P5, female; C, anal somite and left caudal ramus, female (dorsal view); $D$, left caudal ramus, female (ventral view). 


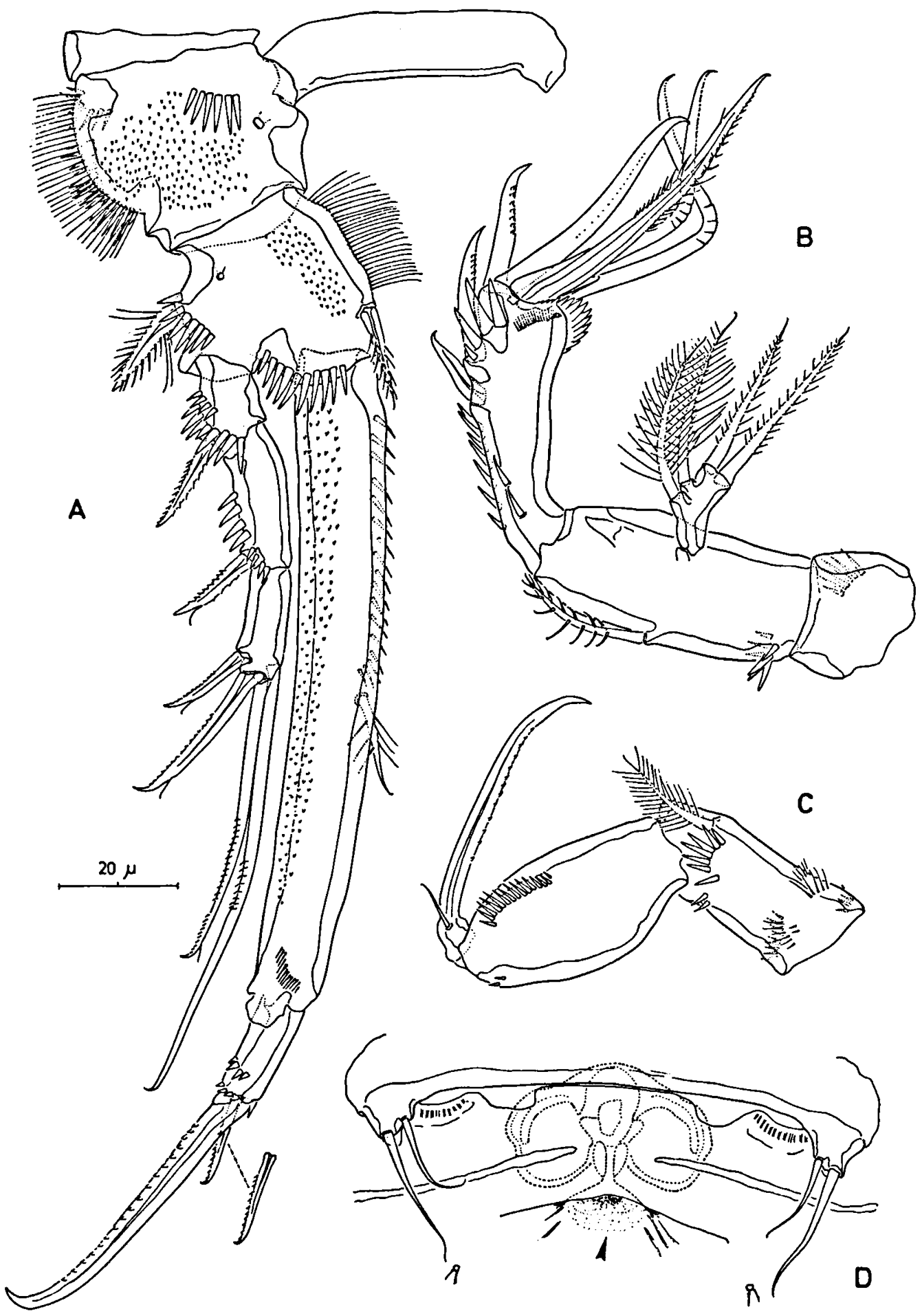

Fig. 3. Laophontopsis borealis n. sp.: A, P1 (anterior view); B, antenna; C, maxilliped; D, genital complex, female (copulatory pore arrowed). 


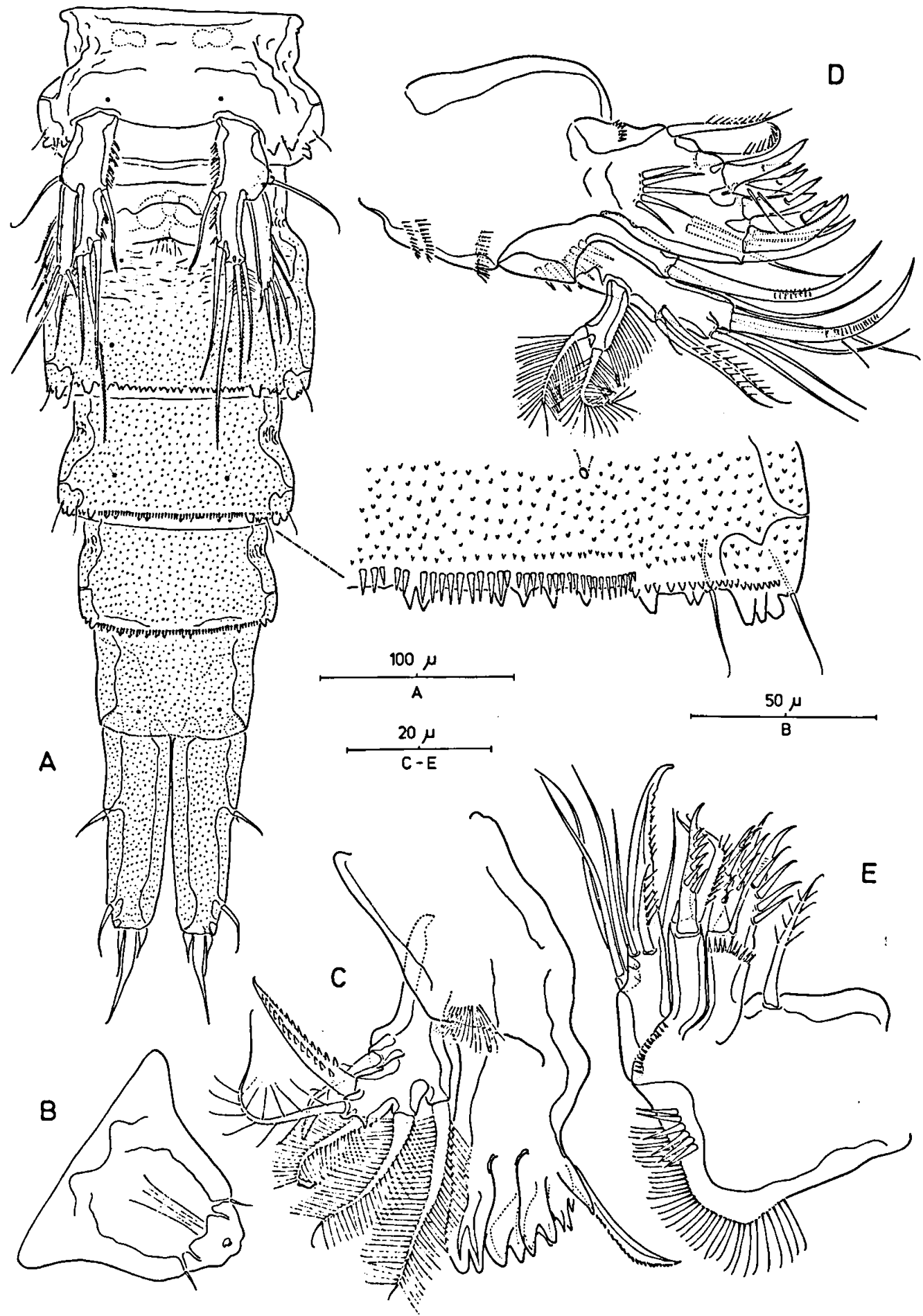

Fig. 4. Laophontopsis borealis $\mathrm{n}$. sp.: A, urosome, female (ventral view); B, rostrum (ventral view); C, mandible; D, maxillula; E, maxilla. 

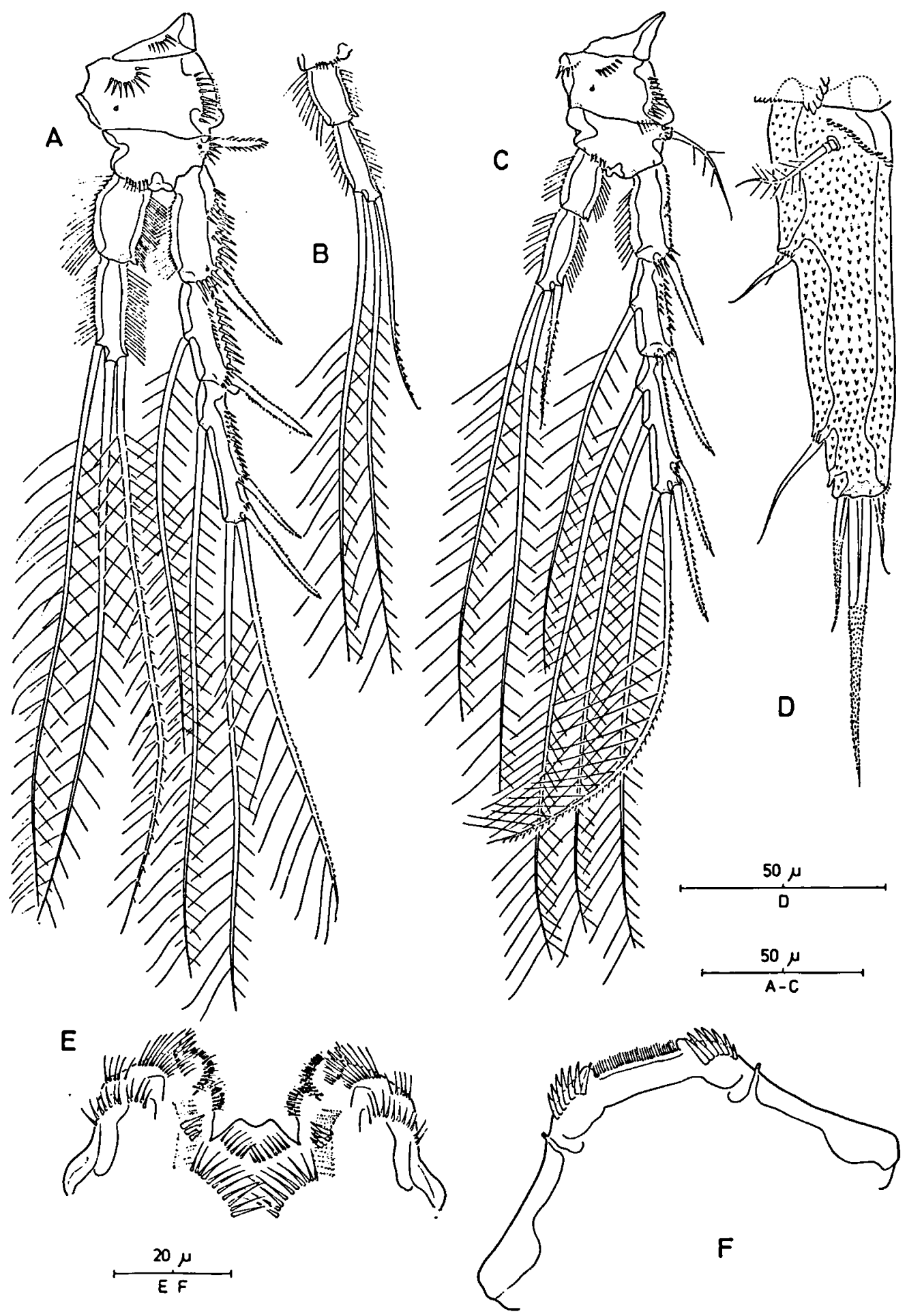

Fig. 5. Laophontopsis borealis n. sp.: A, P2, female; B, endopod P2, male; C, P4, female; D, caudal ramus, male (dorsal view); E, paragnaths; $F$, labrum. 


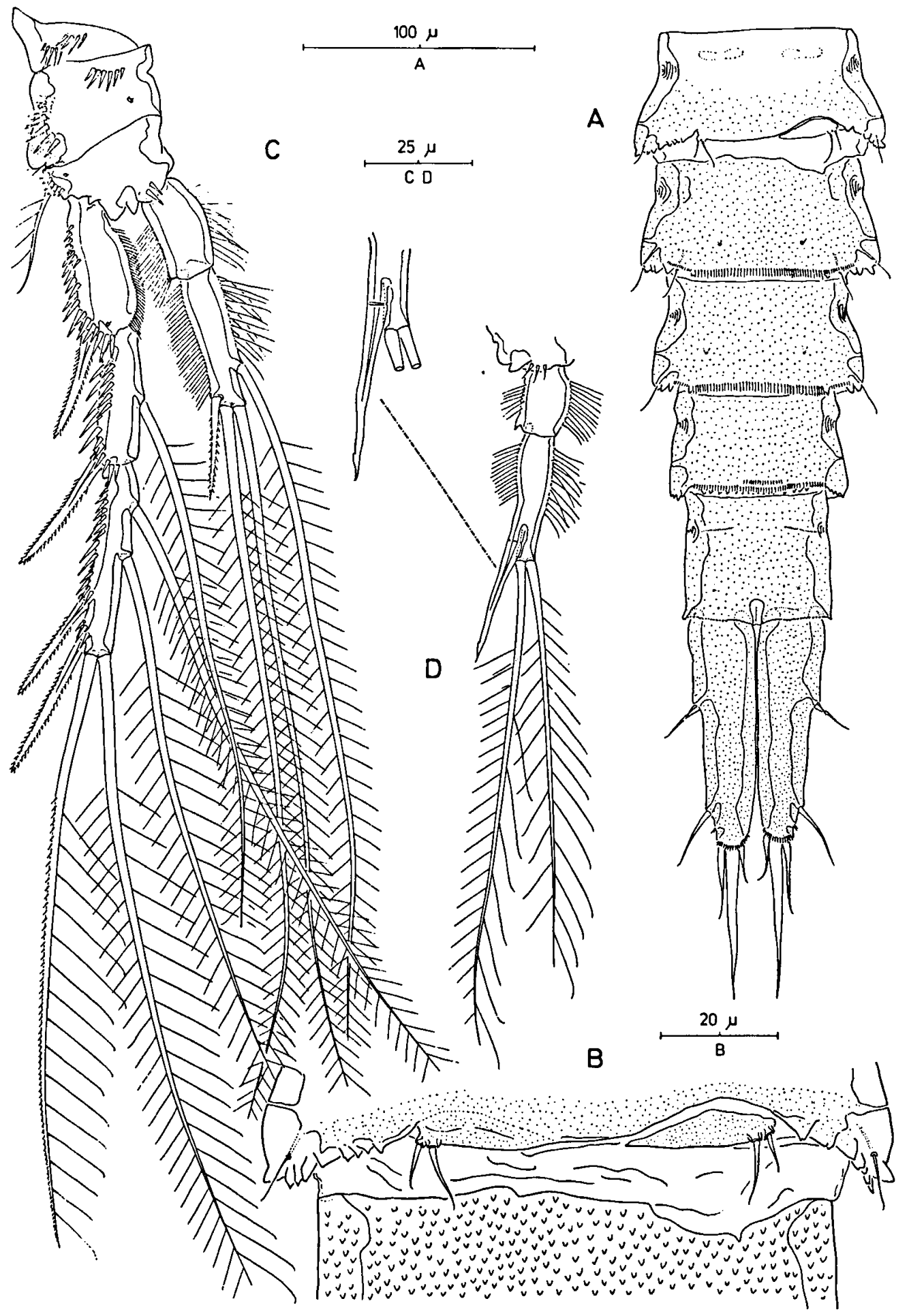

Fig. 6. Laophontopsis borealis n. sp.: A, urosome (excluding P5-bearing somite), male (ventral view); B, P6, male; C, P3, female; D, endopod P3, male. 
Maxilliped (fig. 3C) with 1 plumose seta and several patches of spinules on syncoxa; basis asetose, with inner spinular row; endopod a minute segment with 1 setule and 1 long claw which is denticulate along the inner margin.

Thoracopods with wide intercoxal sclerites and well developed precoxae. Leg 1 (fig. 3A) with large coxa, outer margin with long spinules anteriorly, and 2 rows of short spinules posteriorly; basis with bipinnate spine and long setules at inner margin and with bipinnate spine at outer margin; exp-1, -2 with 1 bipinnate spine, exp-3 with 2 unipinnate spines and 2 geniculate setae; endopod 2.37 times as long as exopod, enp-1 with short inner seta, enp-2 with 1 long and 1 short, denticulate claw.

P2-P4 (figs. 5A, C; 6C). Coxa and basis with secretory pore at anterior surface and with spinular rows along the outer margin; basis with bipinnate spine (P2) or plumose seta (P2-P4). Enp-1 with spinous process at outer distal corner. Seta- and spine formulae as follows:

$\begin{array}{lll} & \text { Exopod } & \text { Endopod } \\ & & \\ \text { P2 } & 0.1 .122 & 0.120 \\ \text { P3 } & 0.1 .222 & 0.121 \\ \text { P4 } & 0.1 .222 & 0 .[0-1] 21\end{array}$

Fifth pair of legs (fig. 2B) laterally displaced (fig. 4A), not fused to supporting somite, rami separate. Baseoendopod forming short, outer setophore bearing basal seta; endopodal lobe longer than exopod, with 2 pectinate spines laterally and 3 bipinnate setae apically; exopod long, with 1 terminal, 1 inner and 4 outer setae.

Genital complex (fig. 3D) with large copulatory pore located in median depression and covered anteriorly by concave, cuticular eminence; P6 a small protuberance with 3 bare setae; gonopores fused to median slit; seminal receptacles paired, circular, close to genital apertures.

Male (figs. 5B, D; 6A, B, D; 7A-E). - Total body length $765 \mu \mathrm{m}$ from the tip of the rostrum to the posterior margin of the caudal rami. Body shape on the whole more slender than in the female (fig. 7A); cephalic shield distinctly tapering anteriorly; integ- umental sculpturing of thoracic somites consisting of large rectangular; depressions genital and first abdominal somites separate (fig. 6A); ventral ornamentation of postgenital urosomites consisting of median row ( 2 on penultimate somite) of slender spinules; anal operculum posteriorly displaced compared to the female.

Sexual dimorphism in antennula, endopod P2-P3, P5, P6 and caudal rami.

Antennula (fig. 7B-D) 5-segmented, modified, geniculation between segments IV and V; segment I with few spinules; segment II without outer, spinous process; segment IV extremely swollen and with complex ornamentation; segment $\mathrm{V}$ with backwardly directed spinous processes ( = modified setae). Setal ornamentation: I-1; II-[1 +8 pinnate]; III-[6 + 4 pinnate]; IV-[6 +5 pinnate + aesthetasc]; V-[7 +3 pinnate +2 modified + aesthetasc].

Endopod of P2 (fig. 5B) narrower than in female; relative proportions of segments about the same but outer apical seta only half the length of its equivalent in the female and unipinnate distally.

Endopod of P3 (fig. 6D) 2-segmented; enp-1 slightly shorter than in female; enp-2 tapering distally, with slender mucroniform process which is homologous with outer seta of enp- 2 of female; apophysis as long as enp- 2 and with distal barb; apical setae considerably shorter than in the female; inner seta absent.

P5 (fig. 7E) defined at base, laterally displaced; baseoendopod with short setophore bearing outer basal seta, and well developed sub-cylindrical endopodal lobe with 1 seta and 1 pectinate spine; exopod defined at base, with 1 inner, 1 apical and 3 outer setae.

Sixth pair of legs (figs. 6A-B) asymmetrical; represented on both sides by a small plate (fused to ventral wall of supporting somite along one side; articulating at base and covering gonopore along the other side) with outer, bilobed process bearing 2 tiny setae. Only one gonopore is functional (the left one in figs. 6A-B). One small, ovoid spermatophore with short neck.

Caudal rami (figs. 5D, 6A, 7A) relatively longer and more slender than in the female. Seta $V 72 \%$ of the total caudal ramus length ( $48 \%$ in female). 


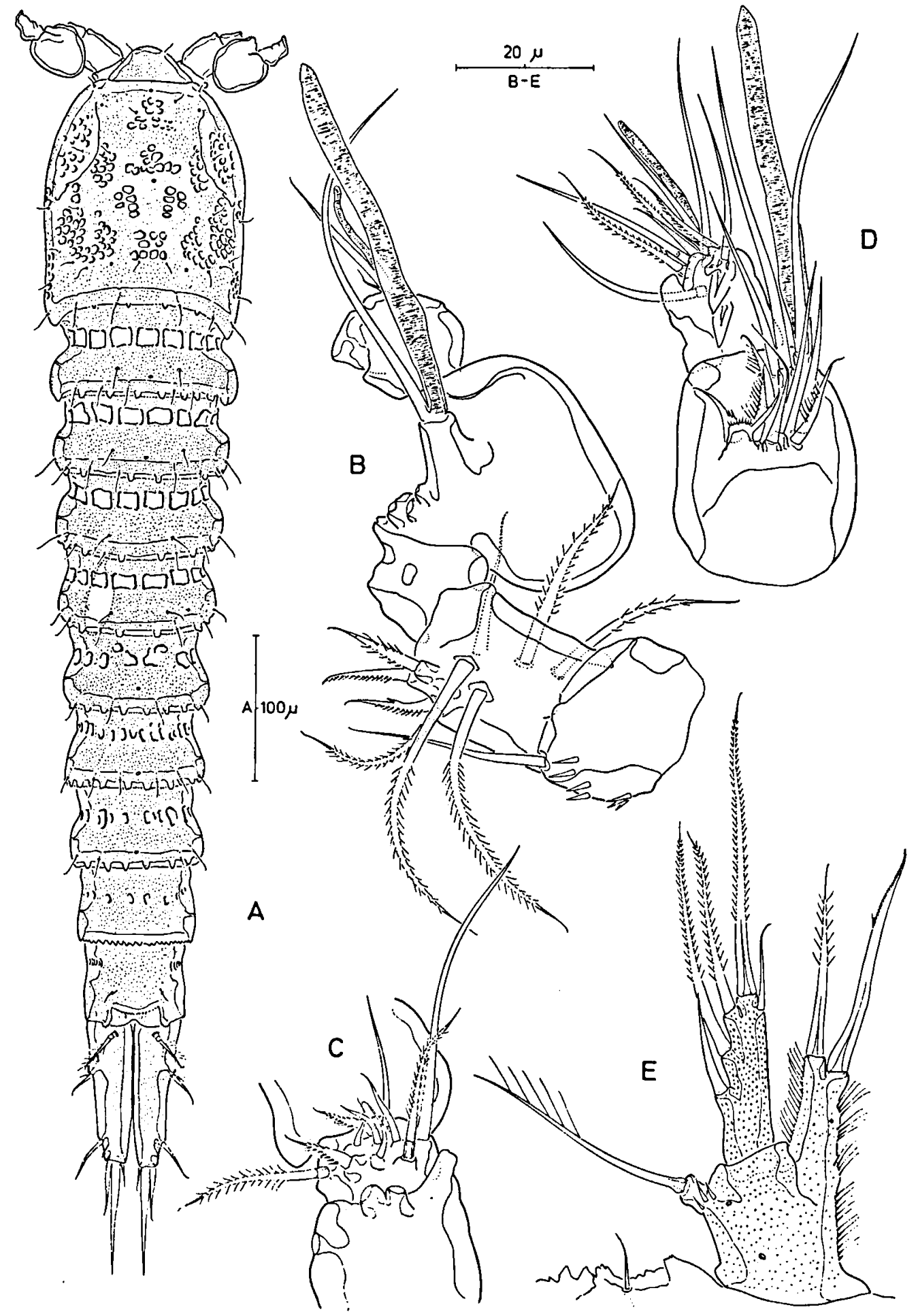

Fig. 7. Laophontopsis borealis n. sp.: A, habitus, male (dorsal view); B, antennula, male (setation of segments II-V omitted); C, antennular segment III, male (anterior view); D, antennular segments IV and V, male (anterior view); E, P5, male. 
Variability (fig. 8). - Found in (1) setation of enp-2 P4; inner seta present (Hvalør and Blakeney Harbour specimens) or absent (Eastern Scheldt specimens); (2) shape of caudal rami.

Etymology. - The species name is derived from the Latin boreas, meaning north, and refers to the distribution of the species.

Material examined. - (1) Three females taken on 18 December 1956 among holdfasts of Laminaria saccharina on the reef of Blakeney Harbour, Norfolk (coll. R. Hamond).

(2) One male and one female taken on 09 September 1981 in the Eastern Scheldt (Dortsman; $51^{\circ} 33^{\prime} 25^{\prime \prime} \mathrm{N} 04^{\circ} 02^{\prime} 02^{\prime \prime} \mathrm{E}$ ), Dutch Delta region, with modified Reineck box corer (coll. K.A. Willems).

(3) University of Oslo, Zoological Museum: 2 females (F. 20286) taken at Hvalør, in the outer part of the Christiania Fjord, Norway (coll. G.O. Sars).

(4) Zoologisches Museum der Universität Kiel: 1 slide (Cop. 687) labeled Laophontopsis lamellifera P.-F. Nr. 125, locality unknown (coll. Dr W. Klie). In fact this slide contains a dissected male of Asellopsis intermedia (T. Scott, 1895).

(5) British Museum (Natural History), London: 1 slide (No. 1947.10.6.32) labeled Laophontopsis (not lamellifera), taken at Hurghada (Al Ghardaqa), Egypt, Red Sea in March 1936 (coll. Dr R. Gurney; identified by Dr A.G. Nicholls). This badly preserved specimen belongs undoubtedly to an undescribed laophontid and not to Laophontopsis.

Remarks. - As mentioned above $L$. borealis spec. nov. can be easily distinguished from the type species on the basis of the $P 1$ and the caudal rami. The population of the Eastern Scheldt deviated from Sars' (1908) redescription and the British material in the setation of the endopod of P4. Due to lack of material it is at present impossible to decide on the significance of this difference. However, since the Dutch specimens agreed in all other aspects, we are inclined to attribute this discrepancy to local variability. The species' distribution is confined to western Europe with records from Norway, Sweden, the British Isles, The Netherlands (present account), Belgium (Herman, pers. comm.) and France.

\section{Laophontopsis monardi spec. nov.}

Laophontopsis lamellifera Monard, 1928 nec (Claus, 1863): 428-429, fig. XLIV-2.
Etymology. - The species is named after the late Dr André Monard who first briefly described it.

Remarks. - The concise but helpful description given by Monard (1928) illustrates clearly that he was dealing with a different species. His specimens cannot be assigned neither to $L$. lamellifera nor to L. borealis. It differs from the former in having a robust $\mathrm{P} 1$ endopod ( 2.3 times the length of the exopod) and very slender caudal rami with a swollen seta $\mathrm{V}$ but diminutive setae IV and VI. The setal formula cannot be used in differentiating it from $L$. lamellifera because it is unknown in the latter; however, it aids to distinguish the material from Banyuls from $L$. borealis, because according to Monard (1928: 429) the exp-3 P4 shows only 5 setae/spines whilst the number in the latter species is 6. The enp-1:exp. ratio of the $\mathrm{P} 1$ is also lower (1.8 compared to 2.0) in Monard's material, and consequently the inner seta of enp-1 inserts at a position clearly proximal (at about the same level in $L$. borealis) to the apical margin of exp-3. Also the distal antennular segment is longer in the mediterranean specimens. We consider the combination of all these differences as sufficient grounds to establish a new species, L. monardi, for this material. The species of Laophontopsis can be distinguished with the following key:

1. Enp. P1 3 times the length of $\exp \ldots \ldots \ldots \ldots \ldots \ldots$ $\ldots \ldots \ldots \ldots \ldots \ldots \ldots$ L. lamellifera (Claus, 1863).

Enp. P1 at most 2.4 times as long as exp. ........ 2

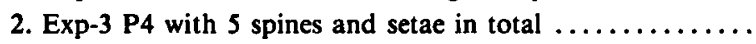
$\ldots \ldots \ldots \ldots \ldots \ldots \ldots \ldots$ L. monardi spec. nov.

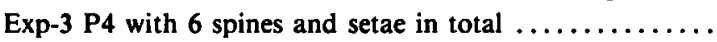
.................... borealis spec. nov.

Aculeopsis gen. nov.

Cleta Claus, 1863 (part.)

Laophontopsis G.O. Sars, 1908 (part.)

Diagnosis. - Laophontopsidae. Antennule with spinous outer process on segment II; in female without trace of incomplete division on segment IV. Antennal exopod with 3 setae and 1 long, bipinnate spine. P1 with exp-2 longer than other exopod segments; enp-1 with short inner seta, enp-2 with 

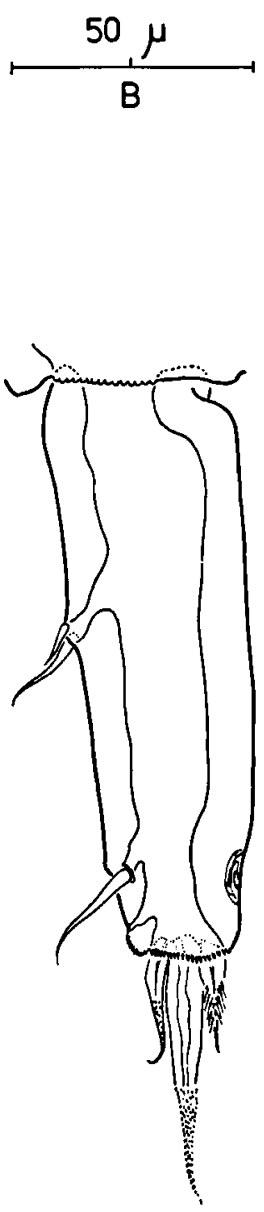

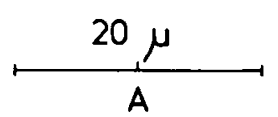

A

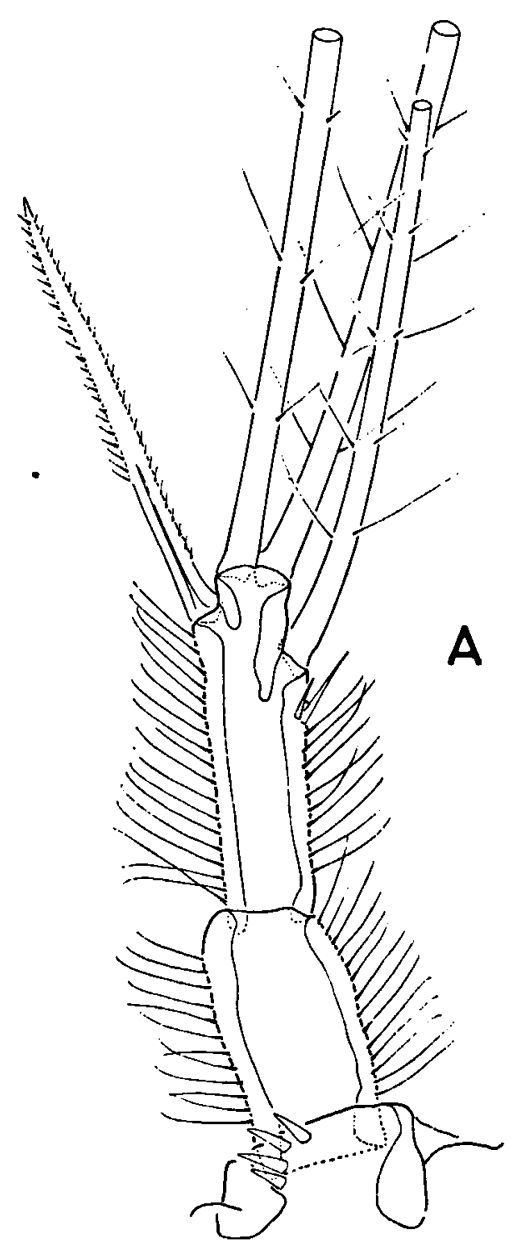

Fig. 8. Laophontopsis borealis n. sp.: A, endopod P4, female (specimen of Sars-collection); B, variation in caudal ramus shape found in Norfolk material.

1 long, unipinnate claw and 1 long, geniculate seta. Exp-3 P2-P4 with 3 outer spines. Exp. P5 longer than endopodal lobe; with 6 setae and/or spines. Caudal rami about twice as long as anal somite; inner terminal seta (V) longest, setae IV and VI reduced.

Type species. - Aculeopsis longisetosa gen. et spec. nov.

Other species. - None.

Etymology. - The generic name is derived from the Latin aculeus, meaning spine, and refers to the spiniform process on the second antennular segment. Gender: feminine.
Aculeopsis longisetosa gen. et spec. nov.

Cleta lamellifera Bodin, 1964 nec Claus, 1863: 152

\section{Description. -}

Female (figs. 9A-C; 10A-C; 11A-C). - Total body length unknown. Rostrum large, with straight anterior margin; ornamented with a pair of tiny setules subterminally and a midventral tube-pore near the apex. Anal somite (fig. 10A) short, about 1.7 times as long as wide, with denticulate, weakly developed operculum flanked by two tiny sensillae; anal vestibulum pentagonal, lateral margins denticulate, hind margins formed by spinular row on cau- 


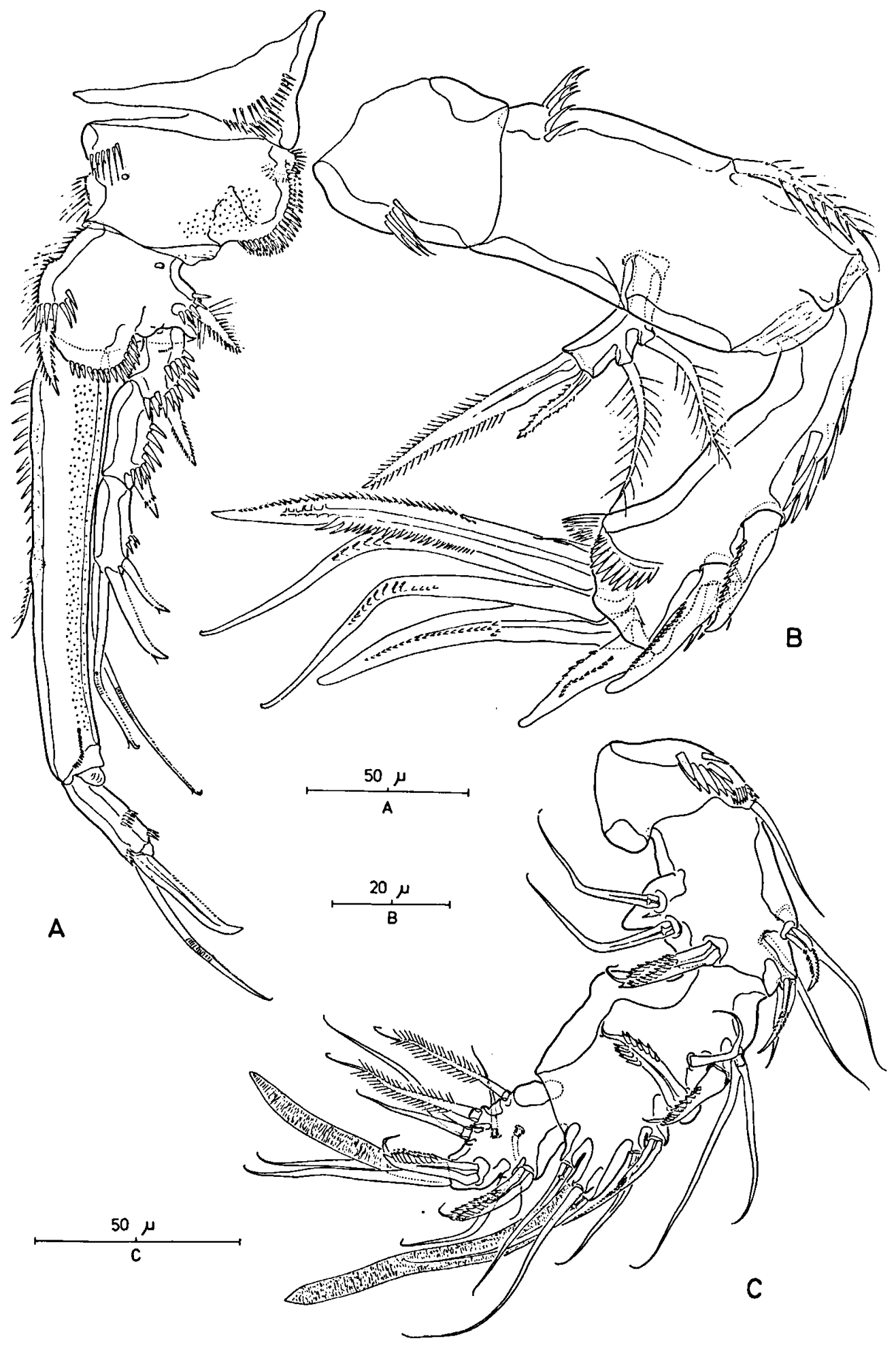

Fig. 9. Aculeopsis longisetosa n. g., n. sp.: A, P1, female; B, antenna; C, antennula, female. 


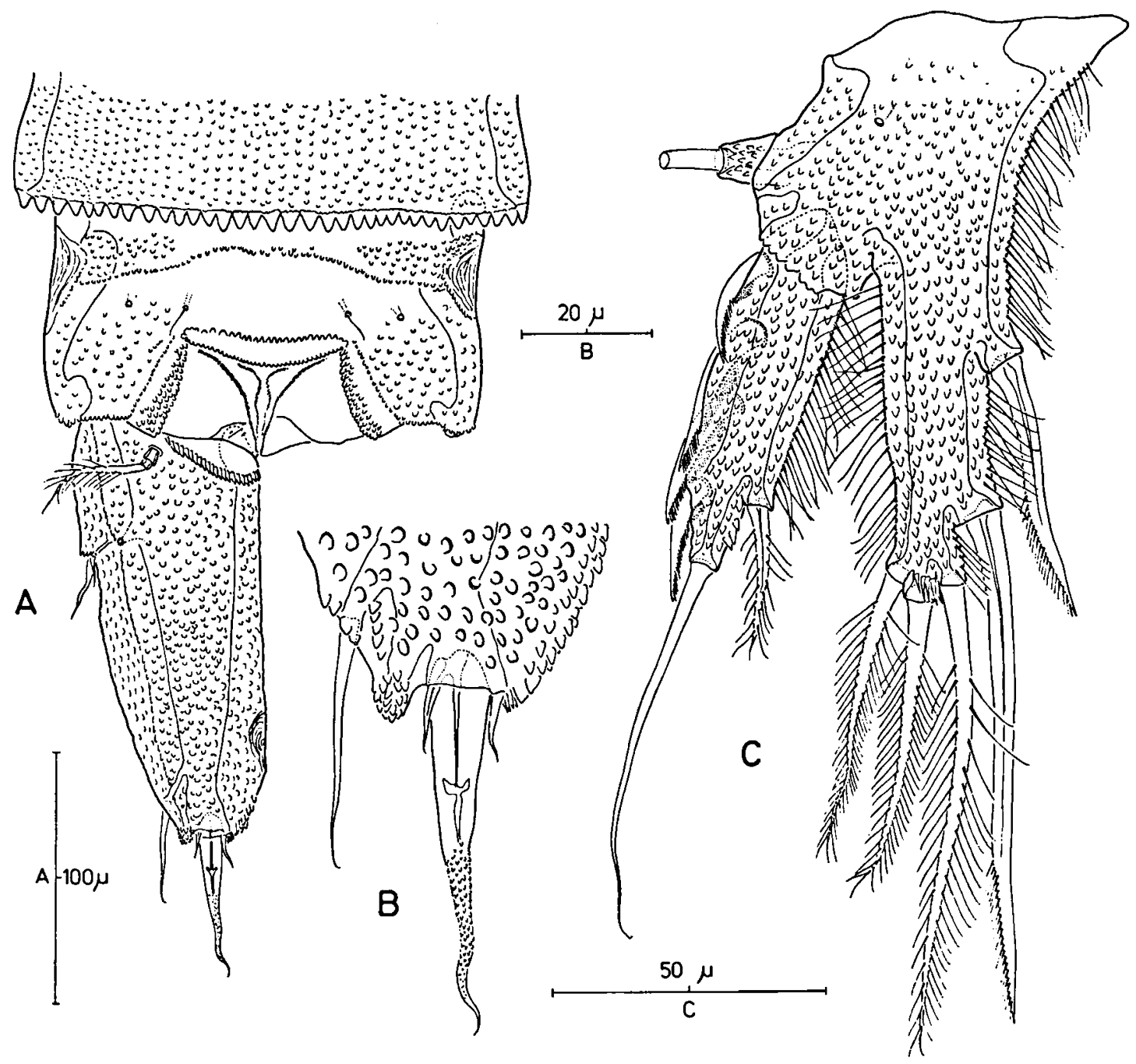

Fig. 10. Aculeopsis longisetosa n. g., n. sp.: A, anal somite and left caudal ramus, dorsal view; B, posterior margin of caudal ramus, dorsal view; C, P5, female (anterior view).

dal rami. Caudal ram (figs. 10B, C) lamelliform, about 2.4 times as long as maximum width; slightly tapering posteriorly; with 7 setae: VII tri-articulated at base, plumose and located near anterior margin; terminal setae IV and VI very reduced, V with diminutive denticles in distal half and fused at base with VI.

Antennula (fig. 9C) 4-segmented, very short. Segment I with 2 spinular rows; segment II with spinous, outer process; segment III longest, outer margin expanded. Setal ornamentation: I-1; II-[4 +4 pinnate]; III-[7 +3 pinnate + aesthetasc]; IV$[7+4$ pinnate + aesthetasc].
Antenna (fig. 9B) with spinular row on coxa; allobasis with spinules proximally and a short, plumose, abexopodal seta; exopod small, with 2 plumose setae laterally and 1 short, pinnate seta and 1 strong, pinnate spine apically; endopod with 2 strong, unipinnate spines laterally, with 2 stout spines and 3 geniculate setae distally (outermost geniculate seta bipinnate and fused with short seta).

Mandible, maxillula, maxilla and maxilliped not drawn, but principally as in Laophontopsis borealis.

Thoracopods with wide intercoxal sclerites and well developed precoxae. Leg 1 (fig. 9A) with large 


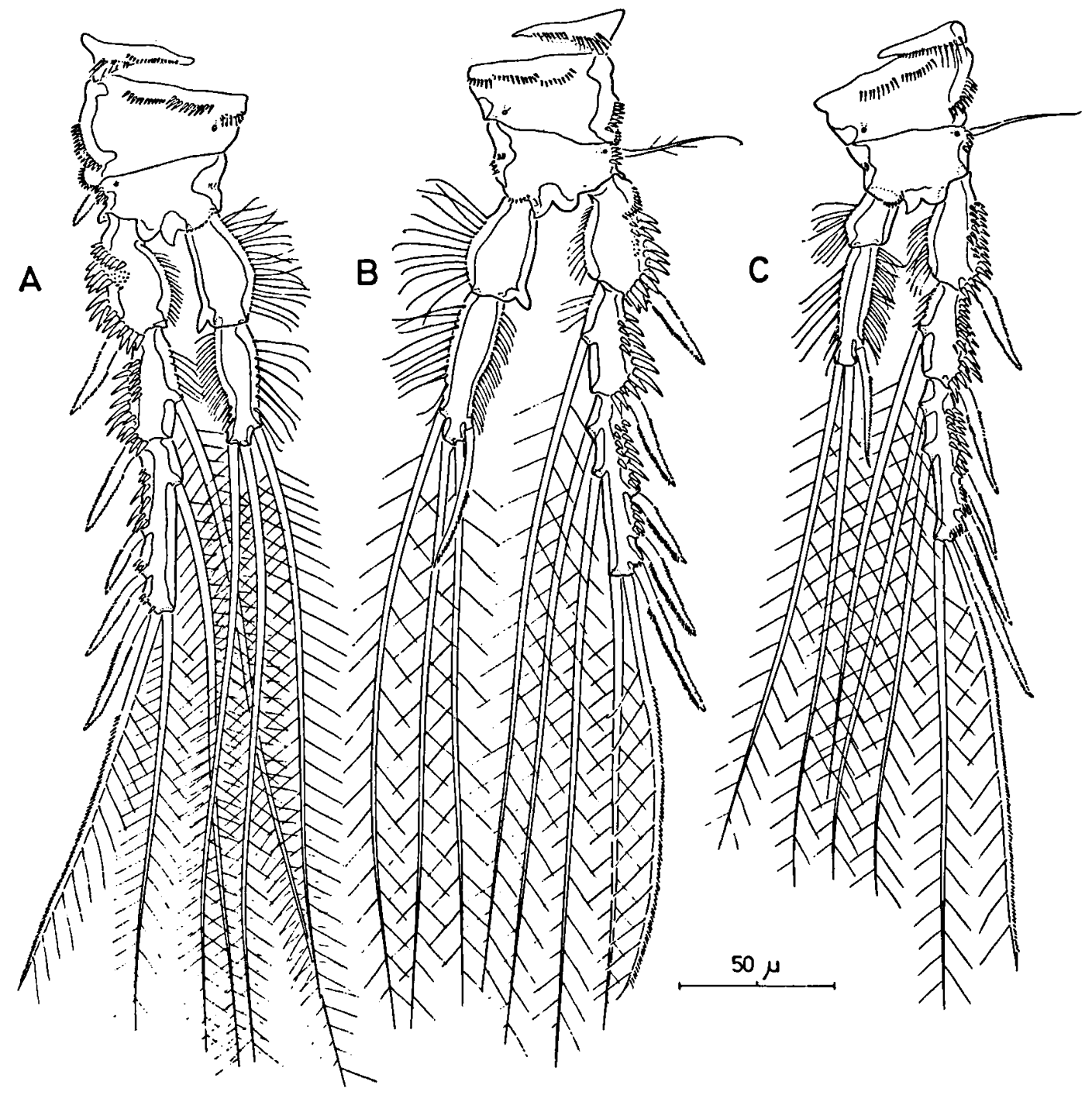

Fig. 11. Aculeopsis longisetosa n. g., n. sp.: A, P2; B, P3; C, P4.

coxa, outer margin with long spinules anteriorly, and 1 row of fine spinules anteriorly, and 1 row of fine spinules posteriorly; basis with bipinnate spine and long setules at inner margin and with bipinnate spine at outer margin; exp-1, -2 with 1 pinnate spine, exp-3 with 2 unipinnate spines and 2 geniculate setae; endopod 2.2 times as long as exopod, enp-1 with short inner seta, enp-2 short, with 1 short, denticulate claw and 1 long geniculate seta.

P2-P4 (figs. 11A-C). Coxa and basis with secretory pore at anterior surface and with spinular rows along the outer margin; basis with bipinnate spine (P2) or plumose seta (P2-P4). Enp-1 with spinous process at outer distal corner. Seta- and spine formulae as follows:

$\begin{array}{lll} & \text { Exopod } & \text { Endopod } \\ \text { P2 } & 0.1 .123 & 0.120 \\ \text { P3 } & 0.1 .223 & 0.121 \\ \text { P4 } & 0.1 .223 & 0.021\end{array}$

Fifth pair of legs (fig. 10C) laterally displaced, not fused to supporting somite, rami separate. Baseoendopod forming short, outer setophore bearing basal seta; endopodal lobe about the same 
length as the exopod, with 2 pectinate spines laterally and 3 bipinnate setae apically; exopod with 1 terminal, 1 inner and 4 outer setae.

Etymology. - The species name is derived from the Latin longus, meaning long, and saeta, meaning bristle, and refers to the long geniculate seta on enp-2 of P1.

\footnotetext{
Material examined. - One female from the Plateau de Chèvres (between beach and Isle of Jarre), Bay of Marseille, Mediterranean, taken at 1 December 1962 (coll. Dr P. Bodin); for location map and details on collection and habitat, vide Bodin (1964); dissected and mounted in gelatinous glycerine on 3 slides.
}

Remarks. - Bodin (1964) regarded this specimen as an aberrant female of $L$. lamellifera because of the different setation found on exp-3 P2-P4 and enp-2 P4. The present redescription however, revealed also important differences in the morphology of the antennula, antenna, P1 and caudal rami. It is very unlikely that all these discrepancies are the result of anomalies. The outer process on the antennula, the ornamentation pattern of the antennal exopod, the long geniculate seta on enp-2 P1 and the presence of 3 outer spines on exp-3 of P2-P4 are features that exclude Bodin's specimen from Laophontopsis and necessitate the establishment of a new genus, Aculeopsis. The discovery of $A$. longisetosa is surprising because its type locality is close to Banyulssur-Mer, the type locality of $L$. monardi. The presence of at least three Laophontopsidae in the Mediterranean and of other representatives in northwest Europe and India indicates that this group is more diverse than previously expected.

Telodocus gen. nov.

Cleta Claus, 1863 (part.)

Laophontopsis G.O. Sars, 1908 (part.)

Diagnosis. - Laophontopsidae. Antennule without spinous outer process on segment II; in female with trace of incomplete division on segment IV. Antennal exopod with 2 setae and 1 long, spear-like, bipinnate spine. $\mathrm{P} 1$ with all exopod segments subequal in length; enp-1 with long inner seta exceeding distal margin of enp-2; enp-2 with 1 long, uni- pinnate claw and 1 long, geniculate seta. Exp-3 P2-P4 with 2 outer spines. Exp. P5 shorter than endopodal lobe; with 5 setae and/or spines. Caudal rami about $4 \frac{1}{2}$ times as long as anal somite; terminal accessory seta (VI) longest, setae IV and V reduced.

Type species. - Cleta secunda Sewell, 1924

Other species. - None.

Etymology. - The generic name is derived from the Greek telos, meaning end, and dokus, meaning spear, and refers to the long spear-like spine at the distal end of the antennal exopod. Gender: masculine.

Telodocus secundus (Sewell, 1924) comb. nov.

Cleta secunda Sewell, 1924: 835, pl. LIV fig. 2.

Remarks. - Sewell (1924) was right when he recognized a close relationship between Cleta secunda and $L$. lamellifera, but we cannot concur with his decision to assign his species to the same genus, because this would expand extensively the diagnosis of Laophontopsis. Cleta secunda differs from all Laophontopsis species in the setation of the antennal exopod ( 3 elements), the endopod of leg 1 (enp1 with very long inner seta; enp-2 with long claw and geniculate seta) and the exopod of P5 (only 5 elements). It shares with $A$. longisetosa the modified spine on the antennal exopod, however, in $C$. secunda it is not only extraordinarily long but also fused to the segment which bears only 2 setae instead of 3 in all other Laophontopsidae. Sewell's (1924) material differs also from Aculeopsis in the absence of an outer process on the antennulae and in having only 2 outer spines on exp-3 P2-P4. C. secunda clearly holds an intermediate position between the primitive genus Aculeopsis and Laophontopsis and we therefore propose a new genus Telodocus to accommodate it. The new genus is also unique in having very long caudal rami (41/2 times the length of the anal somite) with seta VI as the strongest terminal element. 
Discussion. - The Laophontopsidae are assigned to the superfamily Laophontoidea on the basis of the following characters: (1) presence of a spinous outer process on the second antennular segment (retained in Aculeopsis); (2) antenna with allobasis bearing 1 abexopodal seta and tetrasetose, unisegmented exopod; (3) mandible with 1 seta on basis; (4) P1 exopod without inner seta on exp-2, with 4 setae/spines on exp-3; (5) P1 endopod 2-segmented, with inner seta on enp-1, with 2 elements on enp-2; (6) P2-P4 without inner seta on exp-1; (7) sexual dimorphism on leg 3 in male consisting of an apophysis derived from the outer seta of the distal segment in the female; (8) male P6 asymmetrical and ornamentation represented by 2 setae. This suite of characters is significant not only because it defines the superfamily Laophontidae as a monophyletic taxon (Huys, in press a) but also because it is not found in any of the other normanellid genera, thus corroborating the removal of Laophontopsis and allied genera from the Normanellinae. The genus Aculeopsis occupies a primitive position within the Laophontopsidae because of the retention of the spinous process on the antennules, the presence of 3 outer spines on the distal exopod segment of P2-P4 and of 2 well developed armature elements on enp-2 P1. The detailed relationships of the Laophontopsidae within the Laophontoidea will be outlined in a forthcoming paper (Huys, in press a) but it might be useful to list here the discriminating characters between the Laophontidea and the [Laophontopsidae]: (1) rostrum fused to cephalothorax [defined at base], (2) number of antennular segments in female up to 8 [consistently 4], (3) antennular segments distal to geniculation as a rule not fused in the male [fused to 1 segment], (4) except for a few, antennular setae smooth [majority pinnate or plumose]; (5) antennal endopod with 2 spines and 1 seta laterally [2 spines]; (6) maxillula with one basal endite, proximal one absent $[2$ endites]; (7) basis $P 1$ with pedestal for endopod, inner basal spine migrated to anterior surface [no real pedestal; at inner margin]; (8) enp-1 P1 without inner seta [with]; (9) enp-2 P1 with claw + setule [with 2 claws or claw + long geniculate seta]. The two families differ also ecologically, viz. in precopulatory behaviour. In Laophontidae precocious clasping by the male is achieved by grasping the female's P4 (Lang, 1948; Dahms, 1988) whilst there is indication (observations on L. borealis; Monard, 1935a) that in the Laophontopsidae the most widespread (and probably the ancestral) clasping mode is retained, viz. grasping the terminal setae of the female's caudal rami.

Key to the genera of the Laophontopsidae

I. Exp-3 P2-P4 with 3 outer spines; second antennular segment with spinous outer process ........ Aculeopsis gen. nov. Exp-3 P2-P4 with 2 outer spines; second antennular segment without spinous outer process $\ldots \ldots \ldots \ldots \ldots \ldots \ldots 2$

2. Exp-1 with long inner seta (exceeding distal margin of enp-2), enp-2 with slender claw and long geniculate seta; exp. A2 with 2 setae and long spear-like spine; exp. P5 female with 5 setae/spines ................ Telodocus gen. nov. Enp-1 P1 with short inner seta, enp-2 with 1 long and 1 short claw; exp. A2 with 4 setae; exp. P5 female with 4 setae/ spines ................ Laophontopsis Sars, 1908

\section{A revision of the taxonomic concept of the Normanellinae Lang, 1944}

Having justified the removal of Laophontopsis, we are now left with 4 genera in the Normanellinae. Lang (1944) established the subfamily to accommodate Normanella Brady, Cletopsyllus Willey and Pseudocleta Lang (new). A fourth genus Pseudocletopsyllus was proposed by Vervoort (1964). Pseudocleta was created for Willey's (1935) species Laophonte corbula. Lang (1948) recognized a certain affinity between Laophontopsis and Pseudocleta because of the absence of an inner seta on exp-2 P1 and of the presence of only 3 setae on endopod of P2. The Normanella-Cletopsyllus branch was defined on the alternative states of these characters (inner seta on exp-2 P1 present; enp. P2 with 6-7 setae). We cannot support neither of these two statements. The incomplete description of $P$. corbula and the lack of the male make it impossible at the present time to reveal its genuine relationships. However, some morphological features including the moderately slender 6-segmented antennule, the structure of leg 1 and leg 5 , and the shape of the anal operculum definitely preclude Pseudocleta from being a laophontopsid. Alternatively, it cannot be linked neither to Normanella nor to the 
Cletopsyllus-Pseudocletopsyllus lineage and Lang $(1944,1948)$ pointed out previously that it cannot be referred to the Laophontidae either. Under the circumstances it is preferable to rank Pseudocleta as incertae sedis within the Laophontoidae. The presumptive relationship between Normanella and Cletopsyllus is unreal because of fundamental differences in their morphology which allude to a completely different evolutionary history. Significant discrepancies are found in the antennula, antenna, P1, sexual dimorphism of the swimming legs and $\mathrm{P} 6$ of the male. Rather than going into great detail we prefer to establish two subfamilies within the Normanellidae which is elevated herein to full family rank in order to make the boundaries of the Laophontidae more robust. We reckon that the Normanellidae are a diphyletic assemblage and for that reason the family as a whole is not properly diagnosed. Instead, the Normanellinae and Cletopsyllinae subfam. nov. are regarded as monophyletic taxa but since we did not examine carefully representatives of these lineages and relevant information on their affiliations is wanting, we are reluctant to upgrade them to family level although we believe that this will happen in the foreseeable future. It is worthy to note that none of the two subfamilies have close affinities to the Laophontidae and that they cannot be accommodated in the Laophontoidea. The genus Pseudocletopsyllus is tentatively considered incertae sedis within the Cletopsyllinae subfam. nov. because of its juvenile appearance as pointed out previously by Itô (1972).

\section{Subfamily NORMANELLINAE Lang, 1944}

Diagnosis. - Body elongate, sub cylindrical. First pedigerous somite fused to cephalosome. Rostrum triangular, completely defined at the base. Female genital double-somite with internal, transverse, chitinous rib both laterally and dorsally. Anal operculum well developed, rounded; pseudoperculum absent. Caudal rami cylindrical, with 7 setae (V well developed). Sexual dimorphism in antennula, endopod P3 (enp-2 slightly modified, but without real apophysis; 2-segmented), P5, P6, and in genital segmentation; sometimes also in endopod P2.

Antennula without conical projections or outer process; with numerous pinnate and few smooth setae and spines; 5- or 6-segmented in female, with aesthetasc on segment III; modified (segment IV swollen, 2 segments distal to geniculation) in male with geniculation between segments IV and V and with aesthetasc on segment IV. Antenna with basis or allobasis bearing 1 abexopodal seta and unisegmented exopod with 3-4 setae; endopod with 5 distal elements ( 2 spines, 3 geniculate setae) and 2 spines laterally. Mandible with biramous palp; basis with 2 setae; endopod 1-segmented, with 4 setae; exopod 1-segmented, with 1 seta. Maxillule with 1-segmented bisetose exopod; endopod incorporated in basis and represented by 3 setae; two basal endites. Maxillary syncoxa with 3 endites, precoxal endite vestigial (with 1 seta); endopod uni- or twosegmented, with 4 setae. Maxilliped with syncoxa bearing 2 setae; basis asetose; endopod unisegmented with 1 minute seta and 1 long claw.

P1 with well developed 3-segmented protopod; basis forming a long pedestal for endopod, with inner spine located at the inner distal corner; exopod 3-segmented, exp-2 with inner seta, exp-3 with 3 spines and 2 geniculate setae; endopod prehensile, 2-segmented with elongated enp-1 bearing inner seta and short enp-2 with 1 claw, 1 geniculate seta and 1 minute seta. P2-P4 with 3-segmented exopods and 2-segmented endopods; spine- and seta formulae as follows:

$\begin{array}{lll} & \text { Exopod } & \text { Endopod } \\ \text { P2 } & 0.1 .123 & 1 .[2-3] 21 \\ \text { P3 } & 0.1 .223 & 1.321 \\ \text { P4 } & 0.1 .223 & 1.22[0-1]\end{array}$

Female fifth pair of legs not fused medially, defined at the base, intercoxal sclerite absent, exopod and baseoendopod separate; exopod long, with 5-6 setae; endopodal lobe triangular and narrow, with 5-6 setae; basal seta standing on short setophore. Male fifth pair of legs fused medially; endopodal lobe with 2 setae; exopod with 4 setae; basal seta arising from short setophore.

Female gonopores fused medially and each covered laterally by vestigial P6 bearing 3 setae; copulatory pore of moderate size. One egg-sac.

Male P6 symmetrical, with 2-3 setae each; not 
fused at the base with supporting somite. Male grasping terminal setae of female's caudal rami during precopulatory phase.

Marine, freeliving.

Type genus. - Normanella Brady, 1880

Valid species: $N$. minuta (Boeck); $N$. tenuifurca G.O. Sars; $N$. mucronata G.O. Sars; $N$. incerta Lang; $N$. semitica Monard; $N$. quarta Monard; $N$. similis Lang; $N$. serrata Por; $N$. mucronata reducta Noodt; $N$. porosa Noodt; $N$. bolini Lang; $N$. confluens Lang; $N$. aberrans Bodin.

Species inquirenda: $N$. dubia (Brady \& Robertson) [type species; by monotypy].

Other genera. - None.

Subfamily CLETOPSYLLINAE subfam. nov.

Diagnosis. - Body elongate, somites clearly defined with well developed epimeral plates. First pedigerous somite fused to cephalosome. Rostrum triangular, completely defined at the base. Female genital double-somite with internal, transverse, chitinous rib both laterally and dorsally. Anal operculum well developed, ornamented with hairs or long spinules; pseudoperculum absent. Caudal rami cylindrical, sometimes with wide proximal portion, with 7 setae (IV and V well developed). Sexual dimorphism in antennula, endopod P3 (inner apical seta of enp-2 modified into a slender apophysis; 2-segmented), P5, P6, and in genital segmentation; sometimes also in exopod P3, exopod $\mathrm{P} 4$ and caudal rami.

Antennula with 1 or 2 conical projections on segments I-II; with numerous smooth and few pinnate setae and spines; 4-segmented in female, with aesthetasc on segments III and IV; [5- or] 6-segmented and modified (segment [III] IV swollen, always 2 segments distal to geniculation) in male with geniculation between segments [III] IV and [IV] V and with aesthetasc on segment [III] IV. Antenna with basis or allobasis bearing no abexopodal setae, but with minute, unisegmented exopod (sometimes absent; with 1-2 setae); endopod with 5 distal elements ( 2 spines, 3 geniculate setae) and 2 spines plus 1 seta laterally. Mandible with biramous palp; basis with 2-3 setae; endopod 1-segmented, with 4 setae; exopod 1-segmented, with 1 seta. Maxillule with rami incorporated into basis; basal endites fused, reduced. Maxillary syncoxa with 3 endites, precoxal endite vestigial (with 1 seta); endopod unisegmented, with 3 setae. Maxilliped with syncoxa bearing 2-3 setae; basis asetose; endopod unisegmented with 1 seta and 1 long claw.

P1 with well developed 3-segmented protopod; basis forming a long pedestal for endopod, with inner spine located at the inner distal corner; exopod 3-segmented, exp-2 with inner seta, exp-3 with 2 spines and 2 geniculate setae; endopod prehensile, 2-segmented with elongated enp-1 bearing inner seta and short enp-2 with 1 claw, 1 geniculate seta and 0-2 minute setae. P2-P4 with 3-segmented exopods and 2-segmented endopods; spine- and seta formulae as follows:

$\begin{array}{lll} & \text { Exopod } & \text { Endopod } \\ \text { P2 } & 0.1 .123 & 1.421 \\ \text { P3 } & 1.1 .223 & 1.321 \\ \text { P4 } & 1.1 .[2-3] 23 & 1.321\end{array}$

Female fifth pair of legs not fused medially, defined at the base, intercoxal sclerite absent, exopod and baseoendopod separate; exopod long, with 6 setae; endopodal lobe triangular, with 5 setae; basal seta standing on long setophore. Position and segmentation of male fifth pair of legs similar to female; endopodal lobe with 3 setae; exopod with 4-5 setae; basal seta arising from long setophore.

Female gonopores fused medially and each covered laterally by vestigial P6 bearing 1 seta; copulatory pore unconfirmed. One egg-sac.

Male P6 asymmetrical, with 1 seta each; either left or right P6 fused to ventral wall of supporting somite, other member articulating and closing off gonopore. Reproductive system asymmetrical with single functional gonopore releasing one spermatophore at a time. Male grasping terminal setae of female's caudal rami during precopulatory phase.

Marine, freeliving.

Type genus. - Cletopsyllus Willey, 1935.

Valid species: $C$. papillifer Willey (type species; by monotypy); C. secundus Nicholls; $C$. tertius Por; $C$. sagamiensis Itô; $C$. bacescui Marcus; $C$. brattstroemi Geddes; $C$. rotundifera Fiers. 
Genus incertae sedis. - Pseudocletopsyllus Vervoort, 1964

Type species: $P$. spinifer Vervoort (by monotypy).

\section{Acknowledgements}

Grateful thanks are due to Dr Richard Hamond, Morston (Norfolk) and to Dr Philippe Bodin, Université de Bretagne Occidentale, Brest for providing us with specimens. We also thank $\mathrm{Dr}$ Nils Langeland, Zoological Museum, Oslo for allowing us to examine Laophontopsis borealis from the G.O. Sars collection. Part of this research was carried out under EEC science grant no. ST $2 * 0443$. One of us (K.A.W.) acknowledges a grant from the Beyerinck-Popping fund.

\section{References}

Barnett, P.R.O., 1968. Distribution and ecology of harpacticoid copepods on an intertidal mudflat. Int. Revue ges. Hydrobiol., 53: 177-209.

Bodin, P., 1964. Recherches sur la systématique et la distribution des Copépodes Harpacticoïdes des substrats meubles des environs de Marseille. Rec. Trav. Stn. mar. Endoume, 33 (51): 107-183.

Bodin, P., 1976. Les Copépodes Harpacticö̈des (Crustacea) des côtes charentaises (Atlantique). Données écologiques et biologiques sur les espèces principales. Bull. Mus. natn. Hist. nat., (3) 363 (29): 1-45.

Bodin, P., 1977. Les peuplements de Copépodes Harpacticoïdes (Crustacea) des sédiments meubles de la zone intertidale des côtes charentaises (Atlantique). Mém. Mus. natn. Hist. nat., (A) 104: 1-120 + 1-31.

Bodin, P., 1988. Results of ecological monitoring of three beaches polluted by the "Amoco Cadiz" oil spill: development of meiofauna from 1978 to 1984. Mar. Ecol. Prog. Ser., 42: $105-123$.

Bodin, P. \& D. Boucher, 1981. Évolution temporelle du méiobenthos et dù microphytobenthos sur quelques plages touchées par la marée noire de l'Amoco Cadiz. In: “Amoco Cadiz, conséquences d'une pollution accidentelle par les hydrocarbures". Actes du colloque international, Brest, 19-22 novembre 1979, CNEXO éd.: 327-345.

Bossanyi, J. \& H.O. Bull, 1971. The marine fauna of the Cullercoats district. 5. Arthropoda 3c: Crustacea; Copepoda. Rep. Dove mar. Lab., (3) 17: 1-59.

Boxshall, G.A., 1985. The comparative anatomy of two copepods, a predatory calanoid and a particle-feeding mormonilloid. Phil. Trans. r. Soc. London, (B) 311: 303-377.

Brady, G.S., 1872. Contributions to the study of the Entomostraca. No. VII. A list of the non-parasitic marine Copepoda of the north-east coast of England. Ann. Mag. nat. Hist., (4) 10: $1-17$.

Brady, G.S., 1880. A monograph of the free and semi-parasitic
Copepoda of the British Islands, 2: 1-182 (Ray Society, London).

Brady, G.S., 1902. On Copepoda and other Crustacea taken in Ireland and on the north east coast of England. Nat. Hist. Trans. Northumb., 14: 54-68.

Brady, G.S., 1904. Notes on Entomostraca found at the roots of Laminaria. Trans. nat. Hist. Soc. Northumb., (n.S.) 1: 3-9.

Bruce, J.R., J.S. Colman \& N.S. Jones, 1963. Marine fauna of the Isle of Man and its surrounding seas: i-xii, 1-307 (Liverpool University Press).

Calderwood, W.L., 1886. Notes on the copepods of Loch Fyne. Rep. Fishery Bd. Scotl., 4: 147-154.

Canu, E., 1892. Les Copépodes du Boulonnais. Morphologie, embryologie, taxonomie. Trav. Inst. zool. Lille, Trav. Stn. zool. marit. Wimereux, 6: 1-292.

Claparède, E., 1870. Les Annélides Chétopodes du Golfe de Naples. Soc. Phys. Genève, Mém., 20 (2): 365-542.

Claus, C., 1863. Die freilebenden Copepoden mit besonderer Berücksichtigung der Fauna Deutschlands, der Nordsee und des Mittelmeeres: i-x, 1-230, Taf. I-XXXVII (W. Engelmann, Leipzig).

Dahms, H.-U., 1988. Development of functional adaptation to clasping behaviour in harpacticoid copepods (Copepoda, Harpacticoida). Hydrobiologia, 167/168: 505-513.

Duponchel, P.A.J., 1844. Catalogue méthodique des Lépidoptères d'Europe distribués en familles, tribus et genres, avec l'exposé des charactères sur lesquels ces divisions sont fondées, et l'indication des lieux et des époques où l'on trouve chaque espèce, pour servir de complément et de rectification à l'histoire naturelle des Lépidoptères de France, devenue celle des Lépidoptères d'Europe par les supplements qu'on y a ajoutés (Méquignon-Marvis Fils, Paris).

Farran, G.P., 1913. Marine Entomostraca. In: A biological survey of Clare Island in the county of Mayo, Ireland, and of the adjoining district. Proc. r. Ir. Acad., (B) 31 (45): 1-20.

Geddes, D.C., 1972. The Copepoda Harpacticoida of Anglesey and the North Wales coast. Naturalist, Hull, 921: 61-76.

Giard, A., 1888. Le laboratoire de Wimereux en 1888 (recherches fauniques). Bull. sci. Fr. Belg., 19: 492-513.

Herdman, W.A., 1891. Fourth annual report of the Liverpool marine biological station on Puffin Island. Proc. Trans. Lpool biol. Soc., 5: 19-72.

Hicks, G.R.F., 1980. Structure of phytal harpacticoid copepod assemblages and the influence of habitat complexity and turbidity. J. exp. mar. Biol. Ecol., 44: 157-192.

Hicks, G.R.F., 1988. Systematics of the Donsiellinae Lang (Copepoda, Harpacticoida). J. nat. Hist., 22: 639-684.

Hockin, D.C., 1982. The harpacticoid copepod fauna of the River Ythan and its estuary, Aberdeenshire, Scotland. J. mar. biol. Ass. U.K., 62: 729-736.

Hockin, D.C. \& J.G. Ollason, 1981. The colonization of artificially isolated volumes of intertidal estuarine sand by harpacticoid copepods. J. exp. mar. Biol. Ecol., 53: 9-29.

Huys, R., 1988a. On the identity of the Namakosiramiidae Ho \& Perkins 1977 (Crustacea, Copepoda), including a review of 
harpacticoid associates of Echinodermata. J. nat. Hist., 22: 1517-1532.

Huys, R., 1988b. A redescription of the presumed associated Caligopsyllus primus Kunz, 1975 (Harpacticoida, Paramesochridae) with emphasis on its phylogenetic affinity with Apodopsyllus Kunz, 1962. Hydrobiologia, 162: 3-19.

Huys, R., in press a. Amsterdam Expeditions to the West Indian Islands. A new family of harpacticoid copepods and an analysis of the phylogenetic relationships within the Laophontoidea T. Scott. Bijdr. Dierk.

Huys, R., in press b. Pholenota spatulifera Vervoort (Copepoda: Harpacticoida): an aberrant laophontid or a specialized diosaccid? J. nat. Hist.

Huys, R., in press c. Adenopleurella gen. nov., Sarsocletodes Wilson (ex Laophontidae) and Miroslavia Apostolov (ex Cletodidae): representatives of a new family (Copepoda: Harpacticoida). J. Crust. Biol.

Itô, T., 1971. A new species of the genus Cletopsyllus from Sagami Bay (Harpacticoida) Annot. Zool. Jap., 44: 117-124.

Itô, T., 1972. On the fifth copepodid stage of a harpacticoid copepod of the genus Cletopsyllus from Sagami Bay. J. Fac. Sci. Hokkaido Univ., (VI) 18: 406-410.

Jakubisiak, S., 1936. Materjaly do fauny Harpaktikoidów okolic Roscoff (brzegi bretónskie Francji). [Matériaux à la faune des Harpacticoïdes de Roscoff (côtes bretonnes, France)]. Fragm. faun., 2 (28): 315-321.

Lang, K., 1944. Monographie der Harpacticiden (Vorläufige Mitteilung): 1-39 (Almqvist \& Wiksells Boktryckeri Ab, Uppsala).

Lang, K., 1948. Monographie der Harpacticiden: 1-1682, Tab. I-XXXXVII, Karte 1-378, Abb. 1-610 (Håkan Ohlsson, Lund).

Lang, K., 1965. Copepoda Harpacticoida from the Californian Pacific coast. K. svenska VetensAkad. Handl., (4) 10 (2): $1-560$.

Mielke, W., 1984. Some remarks on the mandible of the Harpacticoida (Copepoda). Crustaceana, 46: 257-260.

Monard, A., 1927. Synopsis universalis generum Harpacticoidarum. Zool. Jb. (Syst.), 54: 139-176.

Monard, A., 1928. Les Harpacticoïdes marins de Banyuls. Archs Zool. exp. gén., 67: 259-443.

Monard, A., 1935a. Étude sur la faune des Harpacticoïdes marins de Roscoff. Trav. Stn. biol. Roscoff, 13: 5-88.

Monard, A., 1935b. Les Harpacticoïdes marins de la région de Salammbô. Bull. Stn. océanogr. Salammbô, 34: 1-94.

Monard, A., 1937. Les Harpacticoïdes marins de la région d'Alger et de Castiglione. Bull. Stn. Aquic. Pêche Castiglione, 1935 (2): 9-93.

Moore, P.G., 1973. The kelp fauna of northeast Britain. II. Multivariate classification: turbidity as an ecological factor. J. exp. mar. Biol. Ecol., 13: 127-163.

Mulsant, E., 1850. Species des Coléoptères Trimères Sécuripalpes (Paris).

Nicholls, A.G., 1941. A revision of the families Diosaccidae Sars, 1906 and Laophontidae T. Scott, 1905. (Copepoda, Harpacticoida). Rec. S. Aust. Mus., 7: 65-110.
Nicholls, A.G., 1945. Marine Copepoda from Western Australia. III. Littoral Harpacticoids from Port Denison. J., r. Soc. West. Australia, 29: 1-16.

Norman, A.M., 1886. Museum Normanianum, or a catalogue of the Invertebrata of Europa, and the Arctic and North Atlantic Oceans, which are contained in the collections of the Rev. Canon A.M. Norman, M.A., D.C.L., F.L.S., 3 (Crustacea): 1-26.

Norman, A.M. \& T. Scott, 1906. The Crustacea of Devon and Cornwall: i-xv, 1-232, pls. 1-14 (London).

Norman, A.M. \& G.S. Brady, 1909. The Crustacea of Northumberland and Durham. Trans. nat. Hist. Soc. Northumb. (n. Ser.) 3: 252-417.

O'Riordan, C.E., 1966. The copepod fauna of the inshore plankton of Dalkey, Co. Dublin. Proc. r. Ir. Acad., (B) 64: 355-370.

O'Riordan, C.E., 1971. Meiobenthic Harpacticoida on the east coast of Ireland. Proc. r. Ir. Acad., (B) 71: 91-210.

Pearson, J., 1905. A list of the marine Copepoda of Ireland. Part I. - Littoral forms and fish parasites. Sci. Invest. Fish. Brch. Ire., 1904 (3): 143-170.

Sars, G.O., 1908. Copepoda Harpacticoida. Laophontidae (continued). An Account of the Crustacea of Norway, with short descriptions and figures of all the species, 5 (23-24): 257-276 (Bergen Museum, Bergen).

Scott, A., 1896. Mussels and mussel beds. In: W.A. Herdman, Report on the investigations carried on in 1895 in connection with the Lancashire Sea-Fisheries Laboratory at University College, Liverpool. Proc. Trans. Lpool biol. Soc., 10: 123-134.

Scott, T., 1888. A revised list of the Crustacea of the Firth of Forth. Rep. Fishery Bd. Scotl., 6 (3): 235-262.

Scott, T., 1897. The marine fishes and invertebrates of Loch Fyne. Rep. Fishery Bd. Scotl., 15 (3): 107-174.

Scott, T., 1903. On some new and rare Crustacea collected at various times in connection with the investigations of the Fishery Board for Scotland. Rep. Fishery Bd. Scotl., 21 (3): 109-135.

Scott, T., 1905. On some new and rare Crustacea from the Scottish Seas. Rep. Fishery Bd. Scotl., 23 (3): 141-153.

Scott, T., 1906. A Catalogue of land, fresh-water, and marine Crustacea found in the basin of the River Forth and its Estuary, 2. - The Ostracoda, Copepoda, and Cirripedia. Proc. r. phys. Soc. Edinb., 16: 267-386.

Sewell, R.B.S., 1924. Crustacea Copepoda. In: Fauna of Chilka Lake. Mem. Ind. Mus., 5: 771-851.

Soyer, J., 1966. Copépodes Harpacticoïdes de Banyuls-sur-Mer. 3. Quelques formes du coralligène. Vie Milieu, (B) 17: 303-344.

Thompson, I.C., 1889. Third report on the Copepoda of Liverpool Bay (the L.M.B.C. District). Proc. Trans. Lpool biol. Soc., 3: 181-191.

Thompson, I.C., 1890. On some new and rare Copepoda recently found in Liverpool Bay. Rep. Br. Ass. Advmt. Sci., 59: 638.

Thompson, I.C., 1893. Revised report on the Copepoda of 
Liverpool Bay. Proc. Trans. Lpool biol. Soc., 7: 175-230.

Vervoort, W., 1964. Free-living Copepoda from the Ifaluk Atoll in the Caroline Islands with notes on related species. U.S. natn. Mus. Bull., 236: 1-431.

Wells, J.B.J., 1964. Some additions to the Dale Fort marine fauna. Proc. zool. Soc. London, 142: 453-458.

Wells, J.B.J., 1970. The marine flora and fauna of the Isles of Scilly. Crustacea: Copepoda: Harpacticoida. J. nat. Hist., 4: 255-268.
Willey, A., 1935. Harpacticoid Copepoda from Bermuda, 2 Ann. Mag. nat. Hist., (10) 15: 50-100.

Williams, G., 1954. Fauna of the Strangford Lough and neighbouring coasts. Proc. r. Ir. Acad., (B) 56: 29-133.

Received: 8 August 1989. 